The final publication is available at Springer via http://dx.doi.org/10.1007/s00425-016-2502-x

Krisztina Kovács $^{\mathrm{a}}$, Jiří Pechoušek ${ }^{\mathrm{b}}$, Libor Machala ${ }^{\mathrm{b}}$, Radek Zbořil ${ }^{\mathrm{b}}$, Zoltán Klencsár ${ }^{\mathrm{c}}$, Ádám Solti $^{\mathrm{d}}$, Brigitta Tóth ${ }^{\mathrm{e}}$, Brigitta Müller ${ }^{\mathrm{d}}$, Hong Diep Pham ${ }^{\mathrm{d}}$, Zoltán Kristóf ${ }^{\mathrm{f}}$, Ferenc Fodor $^{\mathrm{d}}$

\title{
Revisiting the iron pools in cucumber roots: identification and localization
}

${ }^{a}$ Institute of Chemistry, Eötvös Loránd University, P.O. Box 32, Budapest 1512, Hungary

${ }^{\mathrm{b}}$ Regional Centre of Advanced Technologies and Materials, Departments of Experimental Physics and Physical Chemistry, Faculty of Science, Palacký University in Olomouc, Olomouc 771 46, Czech Republic

${ }^{c}$ Institute of Materials and Environmental Chemistry, Research Centre for Natural Sciences, Hungarian Academy of Sciences, Magyar tudósok körútja 2, 1117 Budapest, Hungary

${ }^{\mathrm{d}}$ Department of Plant Physiology and Molecular Plant Biology, Institute of Biology, Eötvös Loránd University, Pázmány Péter lane 1/c, Budapest 1117, Hungary

${ }^{\mathrm{e}}$ Department of Botany, Crop Physiology and Biotechnology, Institute of Plant Sciences, Faculty of Agricultural and Food Sciences and Environmental Management, University of Debrecen, 138 Böszörményi Str. Debrecen 4032, Hungary

${ }^{f}$ Department of Plant Anatomy, Institute of Biology, Eötvös Loránd University, Pázmány Péter lane 1/c, Budapest 1117, Hungary

\section{Main Conclusion}

Fe deficiency responses in Strategy I causes a shift from the formation of partially removable hydrous ferric oxide on the root surface to the accumulation of Fe-citrate in the xylem. 


\section{Abstract}

Iron may accumulate in various chemical forms during its uptake and assimilation in roots. The permanent and transient $\mathrm{Fe}$ microenvironments formed during these processes in cucumber which takes up Fe in a reduction based process (Strategy I), have been investigated. The identification of $\mathrm{Fe}$ microenvironments was carried out with ${ }^{57} \mathrm{Fe}$ Mössbauer spectroscopy and immunoblotting, whereas reductive washing and high resolution microscopy was applied for the localization. In plants supplied with ${ }^{57} \mathrm{Fe}^{\mathrm{III}}$-citrate, a transient presence of Fe-carboxylates in removable forms and the accumulation of partly removable, amorphous hydrous ferric oxide/hydroxyde have been identified in the apoplast and on the root surface, respectively. The latter may at least partly be the consequence of bacterial activity at the root surface. Ferritin accumulation did not occur at optimal Fe supply. Under Fe deficiency, highly soluble ferrous hexaaqua complex is transiently formed along with the accumulation of Fe-carboxylates, likely Fe-citrate. As ${ }^{57} \mathrm{Fe}$-citrate is non-removable from the root samples of Fe deficient plants the major site of accumulation is suggested to be the root xylem. Reductive washing results in another ferrous microenvironment remaining in the root apoplast, the Fe $\mathrm{Fe}^{\mathrm{II}}$-bipyridyl complex, which accounts for $\sim 30 \%$ of the total Fe content of the root samples treated for $10 \mathrm{~min}$ and rinsed with $\mathrm{CaSO}_{4}$ solution. When ${ }^{57} \mathrm{Fe}^{\mathrm{III}}$-EDTA or ${ }^{57} \mathrm{Fe}^{\mathrm{III}}$-EDDHA was applied as Fe-source higher soluble ferrous $\mathrm{Fe}$ accumulation was accompanied by a lower total Fe content, confirming that chelates are more efficient in maintaining soluble $\mathrm{Fe}$ in the medium while less stable natural complexes as Fe-citrate may perform better in $\mathrm{Fe}$ accumulation.

\section{Keywords}


Cucumis sativus L. - ferritin - hydrous ferric oxides - iron uptake - Mössbauer spectroscopy

Corresponding author:

Krisztina Kovács

kkriszti@chem.elte.hu

tel: $+3613722500 / 1565$

fax: +3613722592

\section{Abbreviations}

Cit Citrate

EDTA Ethylenediaminetetraacetate

EDDHA Ethylenediamine-N,N'-bis(2-hydroxyphenylacetate)

EELS Electron energy loss spectroscopy

BIP 2,2'-bipyridyl

\section{Author Contribution Statement}

KK and FF conceived and designed research. KK, JP, FF, BT, ZK, BM and HDP conducted experiments. LM and RZ supervised the low-temperature Mössbauer experiments at Palacký University. FF, KK, SA and ZK analyzed data. KK and FF wrote the manuscript. All authors read and approved the manuscript.

\section{Acknowledgements}


The authors wish to thank Frits Bienfait for the discussion on the bypridyl method. This work was supported by the Hungarian National Science Fund grants National Research, Development and Innovation Office - NKFIH PD 111979, PD 112047 and K 115913. The authors gratefully acknowledge the support by the project LO1305 of the Ministry of Education, Youth and Sports of the Czech Republic. This work (Á.S.) was also supported by the Bolyai János Research Scholarship of the Hungarian Academy of Sciences $(\mathrm{BO} / 00207 / 15 / 4)$. 


\section{Introduction}

Roots are the major entering point of nutrients in plants. Iron is an essential micronutrient and its availability to roots is influenced by several factors including $\mathrm{pH}$. Distinct strategies have evolved among plants to acquire Fe. Grass family (Poaceae) species release phytosiderophores to bind $\mathrm{Fe}$ and then take up Fe-complexes (strategy II) while the rest of the plants reduce soluble Fe-chelates at the root surface, aided by the release of protons and phenolic substances (strategy I) (Cesco et al. 2010, Kobayashi and Nishizawa 2012, SisóTerraza et al. 2016). These Fe uptake strategies have been well characterized by describing the genes coding for the transport proteins and by isolating some plant-born Fe binding metabolites e.g. mugineic acids, nicotianamine as well as common organic acids such as citrate participating in Fe trafficking in plants (Abadía 2011). However, much less is known about transient chemical forms of Fe existing in plant roots during the uptake, although it is well known that roots adsorb or take up large amounts of Fe. The characterization of these Fe species suffering reduction, oxidation and complexation processes is a hot topic in improving Fe nutrition and protecting plants against heavy metal toxicity.

Mössbauer spectroscopy was applied to elucidate Fe pools formed in different plants: duckweed, soybean, stocks, pea, rice were investigated (Goodman and Dekock 1982a,b, Kilcoyne et al. 2000, Wade et al. 1993). The main Fe component was identified as ferritin or $\gamma$-FeOOH precipitated on the surface of the roots. Iron biomineralization at acidic conditions was also observed, producing jarosite on the root surface of a perennial grass (Rodríguez et al. 2005, Amils et al. 2007). Measuring the roots of cucumber grown in Hoagland nutrient solution three main $\mathrm{Fe}$ species could be assigned to the $80 \mathrm{~K}$ spectrum of an $\mathrm{Fe}$ sufficient cucumber root: $\mathrm{Fe}^{\mathrm{III}}$-carboxylate complexes $\left(\mathrm{Fe}_{\mathrm{A}}\right)$, a ferritin-like hydrous ferric oxide $\left(\mathrm{Fe}_{\mathrm{B}}\right)$ and a jarosite-like $\mathrm{Fe}^{\mathrm{III}}$-sulphate-hydroxide $\left(\mathrm{Fe}_{\mathrm{C}}\right)$ species (Amils et al. 2007, Kovács et al. 
2009). With the help of further Mössbauer measurements (performed at low temperatures, without and in the presence of an external magnetic field of $5 \mathrm{~T}$ ), the presence of a magnetically ordered (attributed to $\mathrm{Fe}_{\mathrm{B}}$ and $\left.\mathrm{Fe}_{\mathrm{C}}\right)$ and a paramagnetic $\left(\mathrm{Fe}_{\mathrm{A}}\right)$ phase was shown (Kovács et al. 2010). The measurements have confirmed the strategy I Fe uptake mechanism and pointed out that ferrous $\mathrm{Fe}\left(\mathrm{Fe}_{\mathrm{D}}\right)$ accumulates only in $\mathrm{Fe}$ deficient plants where the rate of reduction exceeds that of the uptake and reoxidation upon a short Fe supply at sufficiently high concentration (Kovács et al. 2009). The localization of $\mathrm{Fe}_{\mathrm{A}-\mathrm{D}}$ within the plant root apoplast and symplast remain an open question.

In the present study, an attempt was made to clarify the origin and localization of Fe bearing species in cucumber roots. Mössbauer measurements were used along with several techniques that are able to separate or remove Fe pools formed in the roots: i) a reductive washing procedure with bipyridyl solution was applied to mobilize Fe from the apoplast (Bienfait et al. 1985); ii) root cross sections were analysed by high resolution microscopy to localize Fe accumulated in the tissue; iii) immunoblot studies were performed to identify ferritin apoprotein in the root tissues. The identification of permanent and transient $\mathrm{Fe}$ microenvironments in the root would bring us closer to the understanding of differences between the efficiency of various $\mathrm{Fe}$ sources. In this respect, $\mathrm{Fe}^{\mathrm{III}}$-citrate ( $\mathrm{Fe}^{\mathrm{III}}$-Cit) was compared to $\mathrm{Fe}^{\mathrm{III}}$-EDTA ( $\mathrm{Fe}^{\mathrm{III}}$-ethylenediaminetetraacetate) and $\mathrm{Fe}^{\mathrm{III}}$-EDDHA ( $\mathrm{Fe}^{\mathrm{III}}$ ethylenediamine-N,N'-bis(2-hydroxyphenylacetate)) as the latter ones - being much more stable chelates - are known to efficiently prevent chemical precipitation of $\mathrm{Fe}$ in the apoplast.

\section{Materials and methods}

Plant material 
Cucumber (Cucumis stivus L. cv. Joker F1) plants were grown on unbuffered, modified Hoagland nutrient solution of the following composition: $1.25 \mathrm{mM} \mathrm{KNO}_{3} ; 1.25 \mathrm{mM}$ $\mathrm{Ca}\left(\mathrm{NO}_{3}\right)_{2} ; 0.5 \mathrm{mM} \mathrm{MgSO}{ }_{4} ; 0.25 \mathrm{mM} \mathrm{KH_{2 }} \mathrm{PO}_{4} ; 11.6 \mu \mathrm{M} \mathrm{H}_{3} \mathrm{BO}_{3} ; 4.5 \mu \mathrm{M} \mathrm{MnCl}{ }_{2} .4 \mathrm{H}_{2} \mathrm{O} ; 0.19$ $\mu \mathrm{M} \mathrm{ZnSO} 4.7 \mathrm{H}_{2} \mathrm{O} ; 0.12 \mu \mathrm{M} \mathrm{Na} 2 \mathrm{MoO}_{4} .2 \mathrm{H}_{2} \mathrm{O} ; 0.08 \mu \mathrm{M} \mathrm{CuSO}{ }_{4} .8 \mathrm{H}_{2} \mathrm{O}$ in a climate-controlled growth chamber $\left(14 / 10\right.$ hours light $\left(120 \mu \mathrm{mol}\right.$ photons $\left.\mathrm{m}^{-2} \mathrm{~s}^{-1}\right) /$ dark periods, $24 / 22^{\circ} \mathrm{C}$ and 70/75\% relative humidity). Iron supply and treatments are described below. Each plant was grown individually in $400 \mathrm{ml}$ plastic pots. The solution was replaced with fresh solution every second day, and 16-20 day-old plants were used for the experiments.

Iron supply and treatments

The plants were grown with (Fe sufficient plants) or without Fe (Fe deficient plants). Iron was supplied for Fe sufficient plants as ${ }^{56} \mathrm{Fe}^{\mathrm{III}}$-citrate $\left(\mathrm{Fe} \mathrm{eII}^{\mathrm{III}} \mathrm{Cit}\right),{ }^{57} \mathrm{Fe}^{\mathrm{III}}$-Cit, ${ }^{57} \mathrm{Fe}^{\mathrm{III}}$-EDTA or ${ }^{57} \mathrm{Fe}^{\mathrm{III}}$-EDDHA in $10 \mu \mathrm{M}$ concentration in the nutrient solution. For short term $(30 \mathrm{~min})$ treatment the ${ }^{57} \mathrm{Fe}^{\mathrm{III}}$-Cit, ${ }^{57} \mathrm{Fe}^{\mathrm{III}}$-EDTA or ${ }^{57} \mathrm{Fe}^{\mathrm{III}}$-EDDHA was applied in 500 or $100 \mu \mathrm{M}$ concentrations in fresh nutrient solutions (the latter concentration was applied in only one experiment, Fig. 6). All ${ }^{57} \mathrm{Fe}$-complexes were prepared from ${ }^{57} \mathrm{Fe}$ enriched $(95 \%){ }^{57} \mathrm{FeCl}_{3}$ in water solution. In the case of ${ }^{57} \mathrm{Fe}{ }^{\text {IIII }}$-Cit $1: 1.1 \mathrm{Fe}$ :ligand ratio was applied while for ${ }^{57} \mathrm{Fe}^{\mathrm{III}}$ EDTA and ${ }^{57} \mathrm{Fe}^{\mathrm{III}}$-EDDHA, 5\% excess of Fe was applied (P. Rodriguez-Lucena et al. 2010). In all cases, the $\mathrm{pH}$ of the stock Fe-solutions was adjusted to 5.5.

Without $\mathrm{Fe}$, the $\mathrm{pH}$ of the fresh nutrient solution was 5.06. The $\mathrm{pHs}$ of the nutrient solutions with $500 \mu \mathrm{M} \mathrm{Fe}{ }^{\mathrm{III}}-\mathrm{Cit}, \mathrm{Fe}^{\mathrm{III}}$-EDTA and Fe ${ }^{\mathrm{III}}$-EDDHA were 5.23, 5.25 and 5.30, while at harvest (after $30 \mathrm{~min}$ Fe treatment) they were $5.28 \pm 0.11,4.99 \pm 0.18$ and $5.17 \pm 0.09$ $($ mean $\pm \mathrm{SD}, \mathrm{n}=7)$, respectively. In case of the Fe sufficient plants the pHs with $10 \mu \mathrm{M} \mathrm{Fe}{ }^{\mathrm{III}}-$ 
Cit, Fe ${ }^{\mathrm{III}}$-EDTA and $\mathrm{Fe}^{\mathrm{III}}$-EDDHA were 5.25, 5.16, 5.08, while at harvest (1 day after solution replacement), they were $5.72 \pm 0.02,5.72 \pm 0.00$ and $5.65 \pm 0.05$ (mean $\pm \mathrm{SD}, \mathrm{n}=7)$, respectively. Pictures of the $\mathrm{Fe}$ sufficient and $\mathrm{Fe}$ deficient plants are shown in the Electronic Supplementary Material (Online resource 1).

Removal of apoplastic Fe

To remove apoplast-bound Fe from root samples, a reductive washing procedure was performed based on the work of Bienfait (1985). Whole excised roots were thoroughly rinsed with $0.5 \mathrm{mM} \mathrm{CaSO}_{4}$ solution and gently filtered. Then they were incubated in $0.5 \mathrm{mM} \mathrm{CaSO}_{4}$ solution containing $1.5 \mathrm{mM}$ 2,2'-Bipyridyl (BIP) for $10 \mathrm{~min}$ under reductive conditions by adding sodium dithionite at a final concentration of $5 \mathrm{mM}$ under continuous $\mathrm{N}_{2}$ bubbling through the solution. Apoplastic Fe was removed as $\mathrm{Fe}^{\mathrm{II}}-\left(\right.$ bipyridyl) ${ }^{2+}{ }_{3}\left(\mathrm{Fe}^{\mathrm{II}}-\mathrm{BIP}\right)$ complex, and the tissues were rinsed with $0.5 \mathrm{mM} \mathrm{CaSO}_{4}$ solution then blotted with filter paper. For Mössbauer measurements the root samples were then immediately frozen in liquid $\mathrm{N}_{2}$ while for determination of symplasmic Fe concentration the samples were dried at $80{ }^{\circ} \mathrm{C}$.

Determination of Fe concentration

Measurements were made with three parallel samples following acidic digestion. 5-10 ml $\mathrm{HNO}_{3}$ was added to $1 \mathrm{~g}$ of sample for overnight incubation. Then the samples were predigested for $30 \mathrm{~min}$ at $60{ }^{\circ} \mathrm{C}$. Finally, 2-3 $\mathrm{ml} \mathrm{H}_{2} \mathrm{O}_{2}(30 \mathrm{~m} / \mathrm{m} \%)$ was added for a $90 \mathrm{~min}$ boiling at $120{ }^{\circ} \mathrm{C}$. The solutions were made up to $10-50 \mathrm{ml}$, homogenised and filtered through $\mathrm{MN}$ 640W filter paper. The Fe content of the filtrate was determined by ICP-MS. Fe ${ }^{\text {II }}$ content of 
the samples have been calculated using the contribution of $\mathrm{Fe}^{\mathrm{II}}$ to the Mössbauer spectrum area.

EELS measurements

For electron microscopy and electron energy loss spectroscopy (EELS) studies root samples were fixed primary in $3 \%$ glutaraldehyde for $2 \mathrm{~h}$ and then postfixed in $1 \%$ osmiumtetroxide for 2 h. After dehydration, samples were embedded in Durcupan resin (Fluka-Sigma Aldrich), and 50-70 nm thick sections were cut for both elemental analysis and visualisation.

Elemental analysis was carried out with a Gatan 678 post-column imaging filter (GIF) attached to a $125 \mathrm{kV}$ Hitachi 7100 electron microscope. Spectra were obtained from different areas of the root sections.

All plastids, mitochondria and cell wall sections have been thoroughly examined for dark grains or patches. Elemental analysis was made for all objects suspected to contain Fe.

\section{Gel electrophoresis}

Seed, root and leaf samples were immunoblotted against plant ferritin. Root tips were identified as $\sim 1 \mathrm{~cm}$ tip zone of the individual roots that were covered by root hairs but showed no visible sign of any lateral root formation. Roots with well-developed lateral roots were collected as branching zone samples. Lateral roots were cut off to exclude their root tip zones from the protein samples. Roots that were collected as 'branching zone' samples showed no secondary growth, thus the root parenchyma was well retained in its macromorphology. 
Samples were solubilised in $62.5 \mathrm{mM}$ Tris-HCl, pH 6.8, 2\% SDS, 2\% DTT, 10\% glycerol, and $0.001 \%$ bromophenol blue at room temperature for $30 \mathrm{~min}$. Solubilised proteins were separated according to Laemmli (1970) but in 10-18\% gradient polyacrylamide gels in a MiniProtean apparatus (BioRad) using a constant current of $20 \mathrm{~mA}$ per gel at $6{ }^{\circ} \mathrm{C}$. Protein concentration of samples was determined by comparing the area density with that of a standard mixture using Phoretix 4.01 software (Phoretix International, Newcastle upon Tyne, $\mathrm{UK})$.

To identify ferritin in the tissue samples, immunoblots were carried out. Solubilised proteins were separated by SDS-PAGE were transferred to Whatman ${ }^{\circledR}$ Protran BA83 Nitrocellulose (Whatman GmbH, Germany) membranes in a $25 \mathrm{mM}$ Tris, pH 8.3, $192 \mathrm{mM}$ glicine, $20 \%(\mathrm{v} / \mathrm{v})$ methanol and $0.02 \%(\mathrm{~m} / \mathrm{v})$ SDS at $4{ }^{\circ} \mathrm{C}$ using $90 \mathrm{~V}$ constant voltage $(<0.4$ A) for $3 \mathrm{~h}$. Membranes were decorated with rabbit polyclonal antibodies against plant Ferritin (antibody were obtained from Agrisera AG, Vännäs, Sweden). The antibody was dissolved in $20 \mathrm{mM}$ Tris- $\mathrm{HCl}(\mathrm{pH} 7.5), 0.15 \mathrm{M} \mathrm{NaCl}, 1 \%$ gelatine according to the manufacturer's instructions. Horseradish peroxidase- (HRP-) conjugated goat-anti-rabbit IgG (BioRad, Inc.) was used to detect bands following the manufacturer's instructions. Following the coloration, the membranes were scanned by Epson Perfection V750 PRO gel scanner. The pixel density of the different bands were measured by Phoretix 4.01 software (Phoretix International, Newcastle upon Tyne, UK). The identifications were done following the manufacturers' data (product AS10 674; see: http://www.agrisera.com/en/artiklar/ferritin-plant.html).

\section{Mössbauer spectroscopy}

${ }^{57} \mathrm{Fe}$ Mössbauer measurements at $80 \mathrm{~K}$ were recorded with a conventional Mössbauer spectrometer (WISSEL) operating in the constant acceleration mode and equipped with a 
$3 \times 10^{9} \mathrm{~Bq}{ }^{57} \mathrm{Co} / \mathrm{Rh}$ source. Samples were kept in a helium cryostat (JANIS SVT-400-MOSS) filled with liquid nitrogen. ${ }^{57} \mathrm{Fe}$ Mössbauer spectra were in addition recorded at $5 \mathrm{~K}$ and $2 \mathrm{~K}$ in zero external magnetic field as well as at $2 \mathrm{~K}$ in a $5 \mathrm{~T}$ external magnetic field, using a Spectromag (Oxford Instruments) cryomagnetic system in conjunction with a Mössbauer spectrometer MS96 (Pechousek et al. 2010, 2012). The external magnetic field was applied in the parallel geometry with respect to the propagation of the gamma-rays.

The Mössbauer spectra were evaluated by standard computer-based statistical analysis methods that included fitting the experimental data to a sum of Lorentzians using a leastsquares minimisation procedure for $\chi^{2}$ with the help of the MOSSWINN program (Klencsár et al. 1996). ${ }^{57} \mathrm{Fe}$ isomer shifts are given relative to $\alpha$-iron at room temperature.

Statistical treatment

Statistical analysis was carried out with one-way ANOVA and Tukey-Kramer multiple comparisons test $(\mathrm{p}<0.05)$ using Statistica 2000 (Statsoft) and InStat 3.0 (GraphPad) software.

\section{Results and Discussion}

Iron species in Fe sufficient cucumber roots

In our previous work, according to the Mössbauer spectra of the Fe sufficient cucumber roots without reductive washing taken at both $80 \mathrm{~K}$ (Kovács et al. 2009) and 2-5 K (Kovács et al. 2010), the presence of three main iron bearing components could be suggested: paramagnetic $\mathrm{Fe}^{\mathrm{III}}$-complexes $\left(\mathrm{Fe}_{\mathrm{A}}\right)$, poorly crystallized hydrous ferric oxide (e.g. ferritin) $\left(\mathrm{Fe}_{\mathrm{B}}\right)$ and/or $\mathrm{Fe}^{\mathrm{III}}$-sulphate-hydroxide $\left(\mathrm{Fe}_{\mathrm{C}}\right)$. Paramagnetic $\mathrm{Fe}^{\mathrm{III}}$-complexes were supposed to be located 
mainly in the apoplast while the separation and assignment of hydrous ferric oxide and $\mathrm{Fe}^{\mathrm{III}}$ sulphate-hydroxide could not be done unambiguously. (Kovács et al. 2010).After completing the previous results with the analysis of the Fe sufficient cucumber roots after reductive washing and a parallel analysis of all the low temperature Mössbauer spectra, a more detailed description of the main Fe components present in the Fe sufficient roots can be given. The low-temperature ${ }^{57} \mathrm{Fe}$ Mössbauer spectra of the Fe sufficient cucumber roots before and after reductive washing (i.e. Fe mobilization and removal from the apoplast) are shown in Fig.1 a,b,c (based on Kovács et al. 2010) and d,e,f, respectively. The spectra recorded without an external magnetic field (Fig.1 a,b,d,e) reflect contributions from magnetic (sextet) and paramagnetic (doublet) components. As a result of the application of $5 \mathrm{~T}$ external magnetic field, at $T=2 \mathrm{~K}$ the paramagnetic doublet components are apparently transformed, presumably to a magnetic sextet, resulting in respective components that are not anymore clearly separated from the broad peaks of the main magnetic component (Fig.1 c,f).

Proper decomposition of the spectra in Fig.1 a-f requires the assumption of at least three components in each case. The characteristics of these components could be determined with adequate reliability in the frame of a constrained parallel fit applied separately to the two sets of spectra reflecting the state of cucumber roots before (Fig. 1a,b,c) and after (Fig. 1d,e,f) reductive washing. In the applied fit model we assumed paramagnetic (denoted by $\mathrm{Fe}_{\mathrm{A}}$ and $\mathrm{Fe}_{\mathrm{D}}$ in Table 1,2) and magnetic (denoted by $\mathrm{Fe}_{\mathrm{B} 1}$ and $\mathrm{Fe}_{\mathrm{B} 2}$ in Table 1, 2) components. The hyperfine magnetic field distributions underlying the two magnetic components each have a Gaussian shape, and applied the VBF method (Rancourt \& Ping 1991) as implemented in the MOSSWINN program to account for the corresponding spectral components. Details of the constraints applied during these fits are given in the Electronic Supplementary Material (Online Resource 2), the corresponding results are listed in Table 1 and Table 2 with the associated fitting curves being depicted in Fig. 1a-f. 
The obtained results indicate that the reductive washing alters the nature of the paramagnetic species: before washing, the component $\mathrm{Fe}_{\mathrm{A}}$ with parameters $\delta=0.52(1) \mathrm{mms}^{-1}$, $\Delta=0.58(2) \mathrm{mms}^{-1}, S_{r}=9(2) \%$ can be attributed to high-spin ferric iron in Fe ${ }^{\mathrm{III}}$-carboxylate complexes (as assigned already in Kovács et al. 2009, Kovács et al. 2010), whereas after washing, the doublet component $\left(\mathrm{Fe}_{\mathrm{E}}\right)$ is characterized with parameters $\delta=0.40(1) \mathrm{mms}^{-1}$, $\Delta=0.34(2) \mathrm{mms}^{-1}, S_{r}=5(1) \%$ being indicative of low-spin ferrous iron in distorted octahedral coordination in $\mathrm{Fe}^{\mathrm{II}}$-BIP complex (Greenwood \& Gibb 1975). At the same time, no $\mathrm{Fe}_{\mathrm{A}}$ can be found in the spectra recorded after washing. This confirms our previous assignment of $\mathrm{Fe}_{\mathrm{A}}$ and suggests that these $\mathrm{Fe}^{\mathrm{III}}$-carboxylate complexes are mainly located in the apoplast, and thus, they can be mobilized (via reduction by dithionite and complex formation by BIP) during the washing. It also clearly demonstrates that the resulting $\mathrm{Fe}^{\mathrm{II}}-\mathrm{BIP}$ remains partly attached or is bound again to the cell wall components.

According to the spectra recorded at $2 \mathrm{~K}$ without external magnetic field (Fig. 1b,e) one of the magnetic components $\left(\mathrm{Fe}_{\mathrm{B} 1}\right)$ is characterized by parameters $\delta \approx 0.5 \mathrm{mms}^{-1}, B_{\mathrm{e}, \mathrm{av}} \approx 41 \mathrm{~T}$, $S_{r}=67(1) \%$ (Table 1 , Table 2 ). The relatively low average hyperfine magnetic field is similar to values found for the hydrous ferric oxide core of bacterial and plant ferritins which are in the range of 41-45 T (St. Pierre et al. 1986, Wade et al. 1993, Hartnett et al. 2012). The spectra measured at $T=5 \mathrm{~K}$ (Fig $1 \mathrm{a}, \mathrm{d}$ ) reflects a considerable collapse and broadening of this main magnetic sextet component suggesting that the corresponding magnetic phase undergoes a transition to the paramagnetic state at around $\sim 5 \mathrm{~K}$. The excessive broadening of the peaks of the sextet as observed at $5 \mathrm{~K}$ may refer to the presence of magnetic relaxation phenomena appearing due to the nanosized nature of the associated magnetic particles, as well as to a distribution in the hyperfine magnetic field occurring due to the presence of a multitude of iron microenvironments with slightly different characteristic magnetic transition temperatures. 
It is known that plant and bacterial ferritins have low magnetic ordering temperature $(<4 \mathrm{~K})$ and exhibit a significantly lower hyperfine magnetic field $(40-44 \mathrm{~T})$ than iron-rich mammalian ferritins (48-50 T) due to their amorphous structure and high phosphate content (St. Pierre et al. 1986, Chasteen et al. 1999, Wade et al. 1993, Cornell \& Schwertmann 2003, Hartnett et al. 2012). Therefore, it is plausible to regard the well-developed magnetic sextet component $\mathrm{Fe}_{\mathrm{B} 1}$ in our spectra (at $\mathrm{T}=2 \mathrm{~K}, \mathrm{Fig} .1 \mathrm{~b}, \mathrm{c}$ ) as originating from hydrous ferric oxide particles with probably high phosphate content. It is also noteworthy to mention that the incorporation of organic materials (e.g. organic acids) can also lower the temperature of magnetic ordering and the magnetic hyperfine field as it was shown in synthetic ferrihydrites (Schwertmann et al. 2005)

The $\mathrm{Fe}_{\mathrm{B} 2}$ magnetic component $\left(S_{r}=24 \%\right)$, while having the same isomer shift, displays a considerably smaller average effective magnetic field $\left(B_{\mathrm{e}, \mathrm{a}} \approx 21 \mathrm{~T}\right)$ along with a larger standard deviation $\left(\sigma\left(B_{\mathrm{e}, \mathrm{av}}\right)\right)$ of the associated magnetic field distribution (Table 1,Table 2), which can be the result of magnetic relaxation taking place in the case of particles contributing to $\mathrm{Fe}_{\mathrm{B} 2}$ with a higher frequency than in the case of those contributing to $\mathrm{Fe}_{\mathrm{B} 1}$. With respect to corresponding spectra recorded without external magnetic field, the spectra recorded at $2 \mathrm{~K}$ in conjunction with an external magnetic field of $5 \mathrm{~T}$ (Fig. 1c,f) reveal an increase in the $B_{\mathrm{e}, \mathrm{av}}$ effective magnetic field that is ca. twice of the magnitude of the externally applied field (Table 1,Table 2). This observation clearly confirms our previous supposition that the particles associated with component $\mathrm{Fe}_{\mathrm{B} 2}$ undergo magnetic relaxation even at $2 \mathrm{~K}$. In contrast, $B_{\mathrm{e}, \mathrm{av}}$ of the $\mathrm{Fe}_{\mathrm{B} 1}$ component is perturbed by the external magnetic field to a much lesser extent. Such difference can be readily explained by supposing that the particles contributing to $\mathrm{Fe}_{\mathrm{B} 2}$ are smaller in size than those associated with $\mathrm{Fe}_{\mathrm{B} 1}$ and/or may also reflect differences in their composition (e.g. incorporation of anions or organic acids in its structure). 
The low-temperature Mössbauer spectra of the roots after reductive washing (Fig. 1d,e,f, Table 2) show the presence of magnetic components that can be associated with the same magnetically ordered phases at low temperatures as discussed before $\left(\mathrm{Fe}_{\mathrm{B} 1}\right.$ and $\left.\mathrm{Fe}_{\mathrm{B} 2}\right)$, indicating, that this inorganic Fe phase remains in the root sample abundantly even after the reductive washing. Though the nature of the magnetic components $\mathrm{Fe}_{\mathrm{B} 1}$ and $\mathrm{Fe}_{\mathrm{B} 2}$ (Table 1, Table 2) is not altered considerably by reductive washing, with respect to corresponding parameters observed for the sample before washing (Table 1) one can simultaneously observe a moderate decrease in $B_{\mathrm{e}, \mathrm{av}}$ and a moderate increase in $\sigma\left(B_{\mathrm{e}, \mathrm{av}}\right)$ for both magnetic components at temperatures where they display strongly broadened absorption peaks (i.e. at $5 \mathrm{~K}$ for $\mathrm{Fe}_{\mathrm{B} 1}$ and at $2 \mathrm{~K}$ for $\mathrm{Fe}_{\mathrm{B} 2}$ ). Supposing that this peak broadening is due to magnetic relaxation, the observed changes would refer to a decrease in the magnetic anisotropy energy of the particles resulting in $\mathrm{Fe}_{\mathrm{B} 1}$ and $\mathrm{Fe}_{\mathrm{B} 2}$, which suggests that reductive washing leads to a decrease of the characteristic size of the hydrous ferric oxide particles detected in the Fe sufficient cucumber roots before washing.

The fit results concerning the spectra shown in Fig. 1c,f also elucidate the way of appearance of the $\mathrm{Fe}^{\mathrm{III}}$-carboxylate $\left(\mathrm{Fe}_{\mathrm{A}}\right)$ and $\mathrm{Fe}^{\mathrm{II}}$-BIP $\left(\mathrm{Fe}_{\mathrm{E}}\right)$ related components (being present as doublets in Fig. 1b,e) when the external magnetic field is applied. They each appear as a sextet component displaying a $B_{\mathrm{e}}$ effective magnetic field close to that of the $B_{\text {ext }}=5 \mathrm{~T}$ externally applied field (Table 1, Table 2). In case of $\mathrm{Fe}_{\mathrm{E}}$ (Table 2) $B_{\mathrm{e}}$ is slightly lower than $B_{\text {ext }}$ in accordance with the diamagnetic nature of the low-spin $\mathrm{Fe}^{\mathrm{II}}(S=0)$ state of iron. In contrast, in case of $\mathrm{Fe}^{\mathrm{III}}$-carboxylate $\left(\mathrm{Fe}_{\mathrm{A}}\right)$ with high-spin $\mathrm{Fe}^{\mathrm{III}}$ ions $B_{\mathrm{e}}$ is somewhat larger in magnitude than $B_{\text {ext }}$ (Table 1), which may refer to the appearance of an induced magnetic field in this case. In conjunction with the rather large line width obtained for this component (Table 1), the observation of an induced field could also be connected to magnetic relaxation phenomena taking place in case of component $\mathrm{Fe}_{\mathrm{A}}$, though the strong overlap of this minor 
component with the rest of the peaks prevents us to reach an unambiguous conclusion in this regard on the basis of the present spectra.

Using immunoblotting, ferritin apoprotein was detected in the root branching zone (Fig. 2) as a $\sim 30 \mathrm{kDa}$ protein band, whereas no ferritin accumulation was found in the root tips. No ferritin was detected in solubilized seed and leaf homogenate samples, either. Unspecific binding of the applied antibodies to the non-target proteins was negligible in the samples. In cucumber roots, Vigani et al. (2013) found mitochondrial ferritin accumulation under control $(50 \mu \mathrm{M} F e)$ or Fe-excess $(500 \mu \mathrm{M})$ growth conditions. In our study the Fe concentration in the nutrient solution of control plants was $10 \mu \mathrm{M}$ which seems not to induce ferritin expression. Confirming this assumption, applying transmission electron microscopy, no Fe aggregates typical of ferritin in the root cells could be found (Fig. 3B), but it was revealed that in crevices on the root surface at adjacent cells there is an accumulation of a mucilagous material containing finely dispersed grains (Fig. 3A, C, D). No evidence of a continuous aggregation on the root surface e.g. iron plaque was found which is consistent with our previous study, where Perls/DAB staining and subsequent microscopic analysis of Fe sufficient roots were performed (Fodor et al. 2012).

To clarify the origin and to identify unequivocally the inorganic Fe compound(s), as the major Fe species in the Fe sufficient root, a complete scanning of the root tip zone and lateral root sections have been made by EELS. Our measurements revealed that no ferritin grains or Fe-containing structures can be identified in any root cell compartments. This implies that the majority of the inorganic Fe phase is located outside the root cells forming approx. 20-30 nm grains as it is presented in Fig. 3d and shown by the EELS spectrum taken on the grains (Fig. 4).

Summarizing the results on the major Fe compounds found in the Fe sufficient cucumber root, it is only possible to identify and differentiate between two main Fe containing phases: i) 
$\mathrm{Fe}^{\mathrm{III}}$-complexes and ii) an amorphous Fe-rich hydrous ferric oxide/hydroxide phase, probably including several anions (e.g. phosphate, sulphate) and organic acids (e.g. citrate) in its structure. This is in contrast to previous studies where, in plants, the main Fe bearing compound was identified as ferritin (Goodman et al 1982a, b) or $\gamma$-FeOOH (Kilcoyne et al. 2000). According to our results, $\mathrm{Fe}^{\mathrm{III}}$-complexes were shown to be located in the apoplast while the Fe rich ferric oxide/hydroxide pool is likely to be present mainly on cell surfaces forming small aggregates and probably exhibiting an amorphous structure. Iron taken up and associated to cell functions (heme, Fe-S, Fe-carboxilate complexes etc.) obviously does not give sufficient contribution to the spectra to identify as separate components as its concentration is too low for Mössbauer analysis.

Iron components in Fe deficient cucumber root

The Mössbauer spectra taken at $80 \mathrm{~K}$ of the Fe deficient cucumber roots supplied with 500 $\mu \mathrm{M}{ }^{57} \mathrm{Fe}^{\mathrm{III}}-\mathrm{Cit}$ for $30 \mathrm{~min}$ is presented in Fig. 5A, B. For comparison, the spectra taken after the same Fe supply of the Fe sufficient cucumber root pregrown in Fe ${ }^{\mathrm{III}}$-Cit containing nutrient solution are also shown after $30 \mathrm{~min} 500 \mu \mathrm{M}{ }^{57} \mathrm{Fe}^{\mathrm{III}}$-Cit supply (Fig. 5C). No Mössbauer spectrum could be taken after reductive washing (the amount of ${ }^{57} \mathrm{Fe}$ was under the detection limit; spectrum not shown). In the latter case we utilized the advantage that Mössbauer spectroscopy can only show ${ }^{57} \mathrm{Fe}$ in the samples so in the spectrum presented in Fig. 5C, only new Fe compounds formed during the $30 \mathrm{~min} 500 \mu \mathrm{M}{ }^{57} \mathrm{Fe}^{\mathrm{III}}$-Cit supply can be seen.

The spectra could be evaluated suggesting one or two paramagnetic doublet components with parameters listed in Table 3. According to the Mössbauer parameters, $\mathrm{Fe}_{\mathrm{A}}$ component can be associated to $\mathrm{Fe}^{\mathrm{III}}$ carboxylate complexes already identified in the case of Fe sufficient 
roots (Kovács et al. 2009). The $\mathrm{Fe}_{\mathrm{D}}$ component can be assigned to $\left[\mathrm{Fe}\left(\mathrm{H}_{2} \mathrm{O}\right)_{6}\right]^{2+}$ (Vértes \& Korecz 1979, Kovács et al. 2009) while the $\mathrm{Fe}_{\mathrm{E}}$ represents Fe ${ }^{\mathrm{II}}-\mathrm{BIP}$ complex (Greenwood \& Gibb 1971).

Taking into account previous Mössbauer results on natural $\mathrm{Fe}^{\mathrm{III}}$-complexes applied as $\mathrm{Fe}$ supply for plants (Kovács et al. 2009), the parameters of $\mathrm{Fe}_{\mathrm{A}}$ component are very close to those of Fe $\mathrm{F}^{\mathrm{III}}$-Cit complex $\left(\delta=0.48(1) \mathrm{mms}^{-1}, \Delta=0.62(1) \mathrm{mms}^{-1}\right.$, Solti et al. 2012) supplied in the nutrient solution thus it is supposed to be present as the major $\mathrm{Fe}$ form in the $\mathrm{Fe}$ deficient cucumber root after Fe supply. This result shows that a high amount of the Fe ${ }^{\text {III }}$-Cit present in the nutrient solution can be attached to the cell wall components and taken up by the root. The presence of high amount of a non-removable Fe $\mathrm{F}^{\mathrm{III}}$-Cit component is confirmed by the Mössbauer spectrum taken after the reductive washing since parameters of $\mathrm{Fe}^{\mathrm{III}}$-Cit remains in the spectrum. As the reductive washing completely removes $\mathrm{Fe}^{\mathrm{III}}$-carboxylate components from the apoplastic spaces as we have seen in the roots of Fe sufficient pants, this is only possible if $\mathrm{Fe}^{\mathrm{III}}$-Cit is located inside the cells e.g. in vacuoles or inside the central cylinder of the root. The Fe ${ }^{\text {III }}-$ Cit may be taken up directly from the nutrient solution. Nevertheless it can be formed de novo after the reduction, transport and reoxidation of $\mathrm{Fe}$ in root parenchyma cells. Furthermore, $\mathrm{Fe}^{\mathrm{III}}$-Cit is considered to be the major transport form of Fe in the xylem (Rellán-Álvarez et al. 2010) where the complex may be accumulated taken into account the higher uptake rate of $\mathrm{Fe}$ as compared to Fe sufficient roots. We propose that the $\mathrm{Fe}_{\mathrm{A}}$ component providing the majority of $\mathrm{Fe}$ in the washed $\mathrm{Fe}$ deficient roots is $\mathrm{Fe}^{\mathrm{III}}$-Cit which is localized mainly in the root xylem vessels.

Approximately $10 \%$ of the total $\mathrm{Fe}$ is in the form of $\left[\mathrm{Fe}\left(\mathrm{H}_{2} \mathrm{O}\right)_{6}\right]^{2+}$ in the Fe deficient plants supplied with $\mathrm{Fe}^{\mathrm{III}}$-Cit that confirms previous results showing the highly increased rate of $\mathrm{Fe}$ reduction (turbo reductase activity) (Kovács et al. 2009). Considering that no reduced Fe (Fig. 2C) and only completely removable ferric carboxylates could be found after the same time 
and concentration of Fe supply in the Fe sufficient plants pregrown in ${ }^{56} \mathrm{Fe}^{\mathrm{III}}$-Cit it can be concluded that not only the reduction rate increases under Fe deficiency in Strategy I plants but also the Fe uptake rate becomes significantly higher.

It is noteworthy to mention that the washing procedure also results to the presence of $\mathrm{Fe}^{\mathrm{II}}$ BIP complex $\left(\mathrm{Fe}_{\mathrm{E}}\right.$ found in Fig. 5B). The relative high amount of this complex $(\sim 32 \%$, see Table 3) compared to the Fe sufficient case (see also Fig. 1E, Table 2) can be explained by the much lower total Fe content of the Fe deficient roots. The lack of the ferric oxide/hydroxide species under Fe deficient conditions was also proved by direct low-temperature Mössbauer measurement of an Fe deficient cucumber root supplied with $100 \mu \mathrm{M} \mathrm{Fe}{ }^{\text {III }}$-Cit for 30 min (taken at 5 and $2 \mathrm{~K}$ ). The obtained Mössbauer spectra are presented in Fig. 6, where no magnetically split subspectrum could be separated. The only component can be identified as $\mathrm{Fe}^{\mathrm{III}}-\mathrm{Cit}\left(\delta=0.53(2) \mathrm{mms}^{-1}, \Delta=0.60(4) \mathrm{mms}^{-1}, \Gamma=0.6(1) \mathrm{mms}^{-1}\right)$ confirming the presence of the $\mathrm{Fe}^{\mathrm{III}}-$ Cit component.

Iron components with different Fe supply

Literature data on the uptake of different Fe complexes indicated that there are large differences in the reduction and uptake rate when different $\mathrm{Fe}^{\mathrm{III}}$-chelates were applied (García-Marco et al. 2006, Lucena \& Chaney 2007). The stability and size of the Fe-chelate are major factors influencing the rate of the reduction but similar uptake rate was found for $\mathrm{Fe}^{\mathrm{III}}$-EDTA and Fe $\mathrm{F}^{\mathrm{III}}$-EDDHA complexes (Lucena \& Chaney 2007). On the other hand, the Fe uptake and transport from ${ }^{59} \mathrm{Fe}^{\mathrm{III}}$-Cit compared to ${ }^{59} \mathrm{Fe}^{\mathrm{III}}$-EDTA containing nutrient solution to the shoot of Fe deficient cucumber seedlings was much (2-5 fold) higher (Cseh et al., 1994). 
With the help of Mössbauer spectroscopy, the Fe species formed in Fe sufficient and Fe deficient conditions were investigated in the case of $\mathrm{Fe}^{\mathrm{III}}$-EDTA and $\mathrm{Fe}^{\mathrm{III}}$-EDDHA applied as Fe supply in the nutrient solution in comparison to $\mathrm{Fe}^{\mathrm{III}}$-Cit. The Mössbauer results are presented in Fig. 7 for both the Fe sufficient and deficient case. The corresponding Mössbauer parameters are listed in Table 4.

The Mössbauer spectra and the related Fe-components found in the Fe sufficient Fechelate grown-plants differ from those of the Fe $\mathrm{Fe}^{\mathrm{III}}$-Cit-grown plants. The larger quadrupole doublet characteristic of $\mathrm{Fe}^{\mathrm{IIII}}$ than found for $\mathrm{Fe}^{\mathrm{III}} \mathrm{A}$ (Table 1 and Table 4) and the quite large line width $\left(0.6 / 0.7 \mathrm{~mm} \mathrm{~s}^{-1}\right)$ can refer to the presence of similar but slightly different $\mathrm{O}_{6}$ chemical environment around the $\mathrm{Fe}^{\mathrm{III}}$ ions. This may be explained by the partial attachment of the EDTA, EDDHA ligands to the central $\mathrm{Fe}^{\mathrm{III}}$ but also by the formation of $\mathrm{Fe}^{\mathrm{III}}$ carboxylate complexes with cell-wall components.

Unfortunately, it was difficult to get any information on this component since the very low amount of total Fe in the samples (see also Fig. 8) made impossible even after freezedrying to measure the low-temperature spectra as presented for $\mathrm{Fe}^{\mathrm{III}}$-Cit supplied roots in Fig. 1 and 6. For the same reason, Mössbauer spectroscopy could not be applied following a reductive washing to separate apoplastic and symplastic Fe pools neither in Fe sufficient nor in Fe deficient case. This also suggests that the majority of Fe is taken up and immediately transported to other plant tissues following the reduction and thus, no significant amount of $\mathrm{Fe}$ accumulates in the root parenchyma or in the root apoplast.

The relative and absolute content of $\mathrm{Fe}^{\mathrm{II}}$ in the roots was similar in the case $\mathrm{Fe}^{\mathrm{III}}$-EDTA and Fe ${ }^{\mathrm{III}}$-EDDHA (calculated from the ICP measurements with the help of the relative spectrum areas found in the Mössbauer spectra), while in the case of $\mathrm{Fe}^{\mathrm{III}}$-Cit, they were slightly higher. This shows that the reduction and uptake is favored by the application of $\mathrm{Fe}^{\mathrm{III}}-$ Cit compared to the other $\mathrm{Fe}^{\mathrm{III}}$-chelates. This is also in good agreement with the results 
discussed above for the Fe ${ }^{\mathrm{III}}$-Cit, namely, a very high accumulation of Fe was demonstrated both at Fe sufficient and Fe deficient conditions compared to $\mathrm{Fe}^{\mathrm{III}}$-chelates.

The parameters of the $\mathrm{Fe}_{\mathrm{D}}$ component were slightly different in the roots supplied with $\mathrm{Fe}^{\mathrm{III}}$-chelates from those found in the case of $\mathrm{Fe}^{\mathrm{III}}$-Cit supply. The quadrupole splitting is smaller which may show that the $\mathrm{Fe}^{2+}$ may be partly attached to the EDTA/EDDHA ligand and /or to cell wall $-\mathrm{COO}^{-}$groups. However, no evidence could be found for the formation of $\mathrm{Fe}^{\mathrm{II}}$-EDTA (and probably this holds also for $\mathrm{Fe}^{\mathrm{II}}$-EDDHA) complex since in the latter case, the quadrupole splitting of the complexed $\mathrm{Fe}^{\mathrm{II}}$ would be much smaller $\left(\delta=1.85 \mathrm{mms}^{-1}, \Delta=2.80\right.$ $\mathrm{mms}^{-1}$, measured at $80 \mathrm{~K}$ by Epstein 1962). This contradicts the suggestions made according to previous analytical results that in these systems Fe reduction in the apoplast (Lucena \& Chaney, 2006). Moreover, Mössbauer studies of ${ }^{57} \mathrm{FeCl}_{2^{-}}$ EDTA systems in aqueous solution in acidic and neutral pH-range showed no complex formation between $\mathrm{Fe}^{\mathrm{II}}$ and the ligand but the presence of $\left[\mathrm{Fe}\left(\mathrm{H}_{2} \mathrm{O}\right)_{6}\right]^{2+}$ species (Szilágyi et al., 2007). In the case of EDTA, EDDHA and several other complexing agents, the low stability of the $\mathrm{Fe}^{\mathrm{II}}$-complexes and thus their fast reoxidation after the enzymatic reduction during Fe uptake in cucumber was also proposed (Lucena \& Chaney 2007).

\section{Summary and conclusion}

Attempting to establish a general comparison of Fe uptake from natural complexes e.g. $\mathrm{Fe}^{\mathrm{III}}$-Cit and artificial chelates e.g. $\mathrm{Fe}^{\mathrm{III}}$-EDTA or $\mathrm{Fe}^{\mathrm{III}}$-EDDHA in $\mathrm{Fe}$ sufficient and $\mathrm{Fe}$ deficient plants we have analyzed the microenvironment and localization of Fe components formed during or after the reduction, uptake and accumulation and making up the total $\mathrm{Fe}$ content of the roots of cucumber, a strategy I plant grown in nutrient solution. A long term $\mathrm{Fe}$

supply with $\mathrm{Fe}^{\mathrm{III}}-\mathrm{Cit}$ results in the accumulation of partially removable nanosized amorphous 
hydrous ferric oxide/hydroxide depositions in crevices on the root surface in mucilagous materials. The mucilagous cover on the root surface may be a result of the axenic conditions. Ferric carboxylates can be removed by a reductive washing leaving no sufficient contribution (concentration) of this Fe component to the Mössbauer spectra just as other well-known Fe containing cellular components e.g. Fe-nicotianamine or Fe-S clusters. In Fe deficient plants, short-term $\mathrm{Fe}^{\mathrm{III}}$-Cit supply in high concentration results in fast and efficient accumulation of Fe-carboxylates (most probably $\mathrm{Fe}^{\mathrm{III}}-\mathrm{Cit}$ ) in the xylem and a transient accumulation of $\mathrm{Fe}^{\mathrm{II}}$ at the apoplastic side of the root cell membranes. Our results also show that the reductive washing procedure by the ferrous chelator BIP leaves a significant new, not readily removable Fe component in the root apoplast, the Fe ${ }^{\mathrm{II}}$-BIP complex.

In case of roots supplied with Fe-chelates of high stability (Fe ${ }^{\mathrm{III}}-\mathrm{EDTA}, \mathrm{Fe}^{\mathrm{III}}$-EDDHA) only a $\mathrm{Fe}^{\mathrm{III}}$-carboxylate component suggested to be localized in the apoplast/symplast was identified and no hydrous ferric oxides accumulated. In Fe deficient plants, the ratio of reduced to total $\mathrm{Fe}$ when these stable chelates were supplied almost doubled compared to $\mathrm{Fe}^{\mathrm{III}}$-Cit but it may not necessarily correspond to the higher efficiency of the chelates to supply $\mathrm{Fe}$ as the total $\mathrm{Fe}$ content of these roots were much lower.

It is concluded that natural $\mathrm{Fe}$ chelates, with a similar characteristics to $\mathrm{Fe}^{\mathrm{III}}$-Cit, may perform better in Fe-accumulation in the roots compared to synthetic ones. This may be utilized in $\mathrm{Fe}$ biofortification, since nanosized $\mathrm{Fe}$ deposits on the root surface may be remobilized upon Fe deficiency. Thus, compared to highly stable synthetic chelates that perform better in maintaining $\mathrm{Fe}$ in soluble form, also natural Fe chelates could provide a good choice to prevent Fe deficiency in irrigated plantations. 


\section{References}

Abadía J, Vázquez S, Rellán-Álvarez R, El-Jendoubi H, Abadía A, Álvarez-Fernández A, López-Millán AF (2011) Towards a knowledge-based correction of iron chlorosis. Plant Physiol Bioch 49: 471-482.

Amils R, de la Fuente V, Rodríguez N, Zuluaga J, Menéndez N, Tornero J (2007) Composition, speciation and distribution of iron minerals in Imperata cilíndrica. Plant Physiol Bioch 45: 335-340.

Bienfait HF, Briel WVD, Mesland-Mul NT (1985) Free space iron pools in roots: generation and mobilization. Plant Physiol 78: 596-600.

Briat JF, Duc C, Ravet K, Gaymard F (2010) Ferritins and iron storage in plants. Biochim Biophys Acta 1800: 806-814.

Cesco S, Neumann G, Tomasi N, Pinton R, Weisskopf L (2010) Release of plant-borne flavonoids into the rhizosphere and their role in plant nutrition. Plant Soil 329:1-25.

Chasteen ND, Harrison PM (1999) Mineralization in Ferritin: An Efficient Means of Iron Storage. J Struct Biol 126: 182-194.

Cornell RM, Scwertmann U (2003) The iron oxides. Weinheim: Wiley-VCH. 
Cseh E, Váradi G, Fodor F (1994) Effect of Fe-complexes and N-forms on the Fe absorption, uptake and translocation of cucumber plants. Bot Kozl 81: 47-55.

Epstein LM (1962) Mössbauer Spectra of Some Iron Complexes. J Chem Phys 36: 27312737.

Fodor F, Kovács K, Czech V, Solti Á, Tóth B, Lévai L, Bóka K, Vértes A (2012) Effects of short term iron citrate treatments at different $\mathrm{pH}$ values on roots of iron deficient cucumber: a Mössbauer analysis. Journal of Plant Physiology, 169:1615-1622.

García-Marco S, Martínez N, Yunta F, Hernandez-Apaolaza L, Lucena JJ (2006) Effectiveness of ethylenediamine-N(o-hydroxyphenylacetic)-N'(p-hydroxyphenylacetic) acid (o,p-EDDHA) to supply iron to plants. Plant Soil 279:31-40.

Goodman BA, DeKock PC (1982a) Mössbauer studies of plant materials. I. Duckweed, stocks, soyabean and pea. J Plant Nutr 5: 345-353.

Goodman BA, DeKock PC (1982b) Mössbauer studies of plant materials. II. Spectra of ${ }^{57} \mathrm{Fe}-$ enriched duckweed at low temperatures. J Plant Nutr 5: 355-362.

Greenwood NN, Gibb TC (1971) Mössbauer Spectroscopy. Chapman \& Hall Ldt., London, UK 
Hartnett A, Böttger LH, Matzanke BF, Carrano CJ (2012) A multidisciplinary study of iron transport and storage in the marine green alga Tetraselmis suecica. J Inorg Biochem 116: $188-194$.

Kilcoyne SH, Bentley PM, Thongbai P, Gordon DC, Goodman BA (2000) The application of

${ }^{57} \mathrm{Fe}$ Mössbauer spectroscopy in the investigation of iron uptake and translocation in plants. Nucl Instrum Meth B 160: 157-166.

Klencsár Z, Kuzmann E, Vértes A (1996) User-friendly software for Mössbauer spectrum analysis. J Radioanal Nucl Ch 210: 105.

Kobayashi T, Nishizawa NK (2012) Iron uptake, translocation, and regulation in higher plants. Annu Rev Plant Biol 63: 131-152.

Kovács K, Kuzmann E, Fodor F, Homonnay Z, Machala L, Vértes A (2010) Low temperature ${ }^{57}$ Fe Mössbauer study of cucumber root, J Phys Conf Ser 217: 012019

Kovács K, Kuzmann E, Tatár E, Vértes A, Fodor F (2009) Investigation of iron pools in cucumber roots by Mössbauer spectroscopy: direct evidence for the Strategy I iron uptake mechanism. Planta 229: 271-278.

Laemmli UK (1970) Cleavage of structural proteins during assembly of the head of bacteriophage T4. Nature 227: 680-685. 
Lucena JJ, Chaney RL (2006) Synthetic Iron Chelates as Substrates of Root Ferric Chelate Reductase in Green Stressed Cucumber Plants. J Plant Nutr 29: 423-439.

Lucena JJ, Chaney RL. (2007) Response of Cucumber Plants to Low Doses of Different Synthetic Iron Chelates in Hydroponics. J Plant Nutr 30: 795-809.

Pechousek J, Jancik D, Frydrych J, Navarik J, Novak P (2012) Setup of Mössbauer spectrometers at RCPTM. Mossbauer Spectroscopy in Materials Science 1489: 186-193.

Pechousek J, Prochazka R, Jancik D, Frydrych J, Mashlan M (2010) Universal LabVIEW powered Mössbauer spectrometer based on the USB, PCI or PXI devices. J Phys Conf Ser 217: 1-4.

Rancourt DG, Ping JY (1991) Voigt-based methods for arbitrary-shape static hyperfine parameter distributions in Mössbauer spectroscopy. Nuclear Instruments and Methods B 58: $85-97$.

Rellán-Álvarez R, Giner-Martínez-Sierra J, Orduna J, Orera I, Rodríguez-Castrillón JÁ, García-Alonso JI, Abadía J, Álvarez-Fernández A (2010) Identifi cation of a Tri-Iron(III), TriCitrate Complex in the Xylem Sap of Iron-Defi cient Tomato Resupplied with Iron: New Insights into Plant Iron Long-Distance Transport. Plant Cell Physiol 51(1): 91-102.

Rodríguez N, Menéndez N, Tornero J, Amils R, de la Fuente V (2005) Internal iron biomineralization in Imperata cylindrica, a perennial grass: chemical composition, speciation and plant localization. New Phytol 165: 781-789. 
Rodriguez-Lucena P, Benedicto A, Lucena JJ, Rodriguez-Castrillon JA, Moldovan M, Alonso JIG and Hernandez-Apaolazaa L (2010) Use of the stable isotope ${ }^{57} \mathrm{Fe}$ to track the efficacy of the foliar application of lignosulfonate $/ \mathrm{Fe}^{3+}$ complexes to correct Fe deficiencies in cucumber plants. J Sci Food Agr 91: 395-404.

Sisó-Terraza P, Rios JJ, Abadía J, Abadía A, Álvarez-Fernández A (2016) Flavins secreted by roots of iron-deficient Beta vulgaris enable mining of ferric oxide via reductive mechanism. New Phytologist 209:733-745.

Schwertmann U, Wagner F, Knicker H. (2005) Ferrihydrite-Humic Associations: Magnetic Hyperfine Interactions. Soil Sci Soc Am J 69:1009-1015.

Solti Á, Kovács K, Basa B, Vértes A, Sárvári É, Fodor F (2012) Uptake and incorporation of iron in sugar beet chloroplasts. Plant Physiol Bioch 52: 91-97.

St. Pierre TG, Bell SH, Dickson DPE, Mann S, Webb J, Moore GR and Williams RJP (1986) Mössbauer spectroscopic studies of the cores of human, limpet and bacterial ferritins. Biochim Biophys Acta 870: 127-134.

Szilágyi ÁP (2007) Study of iron-chelates in solid state and aqueous solutions using Mossbauer spectroscopy. Dissertation, Eötvös Lorand University, Budapest, Hungary

Vértes A, Korecz L, Burger K (1979) Mössbauer spectroscopy. Elsevier, Amsterdam 
Vigani G, Tarantino D, Murgia I (2013) Mitochondrial ferritin is a functional iron-storage protein in cucumber (Cucumis sativus) roots. Front Plant Sci 4: 316.

Wade VJ., Treffry A, Laulhere JP, Bauminger ER, Cleton MI, Mann S, Briat JF and Harrison PM (1993) Structure and composition of ferritin cores from pea seed (Pisum sativum). Biochim Biophys Acta 1161: 91-96. 


\section{Table 1}

${ }^{57} \mathrm{Fe}$ Mössbauer parameters of $\mathrm{Fe}$ components found in the $\mathrm{Fe}$ sufficient cucumber roots grown on $\mathrm{Fe}^{\mathrm{III}}$-Cit for 3 weeks, as derived on the basis of measurements performed at temperatures $5 \mathrm{~K}$ and $2 \mathrm{~K}$, as well as at $2 \mathrm{~K}$ in an external magnetic field of $B_{\text {ext }}=5 \mathrm{~T}$ being oriented parallel to the direction of gamma ray (Fig 1a-c). Parameter values that are indicated to be the same were constrained to be the same during the fit. For magnetic components where the double quadrupole shift $(2 \mathcal{\varepsilon})$ is not given, it was assumed to be zero. The numbers between parentheses give the statistical uncertainty $(1 \times$ standard deviation $)$ in the last digit. The suffix $F$ refers to a fixed parameter.

\begin{tabular}{|l|c|c|c|}
\hline & $T=5 \mathrm{~K}$ & $T=2 \mathrm{~K}$ & $T=2 \mathrm{~K}, B_{\mathrm{ext}}=5 \mathrm{~T}$ \\
\hline $\mathbf{F e}_{\mathbf{A}}$ & & & $0.52(1)$ \\
\hline$\delta^{\mathrm{a}}\left(\mathrm{mms}^{-1}\right)$ & $0.52(1)$ & $0.52(1)$ & - \\
\hline$\Delta^{\mathrm{b}}\left(\mathrm{mms}^{-1}\right)$ & $0.58(4)$ & $0.58(4)$ & $7.1(2)$ \\
\hline$B_{\mathrm{e}}^{\mathrm{c}}(\mathrm{T})$ & - & - & $1.08(7)$ \\
\hline$\Gamma^{\mathrm{d}}\left(\mathrm{mms}^{-1}\right)$ & $1.08(7)$ & $1.08(7)$ & $9(2)$ \\
\hline$S_{\mathrm{r}}^{\mathrm{e}}(\%)$ & $9(2)$ & $9(2)$ & $0.504(3)$ \\
\hline $\mathbf{F e}_{\mathbf{B} 1}$ & & & $-0.08(1)$ \\
\hline$\delta^{\mathrm{a}}\left(\mathrm{mms}^{-1}\right)$ & $0.504(3)$ & $0.504(3)$ & $43.2(1)$ \\
\hline $2 \varepsilon^{\mathrm{f}}\left(\mathrm{mms}^{-1}\right)$ & $0 \mathrm{~F}$ & $-0.05(1)$ & $4.4(1)$ \\
\hline$B_{\mathrm{e}, \mathrm{av}}{ }^{\mathrm{c}}(\mathrm{T})$ & $25.7(2)$ & $41.0(1)$ & $0.69(1)$ \\
\hline$\sigma\left(B_{\mathrm{e}}\right)^{\mathrm{g}}(\mathrm{T})$ & $14.6(3)$ & $4.8(1)$ & $67(1)$ \\
\hline$\Gamma^{\mathrm{d}}\left(\mathrm{mms}^{-1}\right)$ & $0.69(1)$ & $0.69(1)$ & $0.504(3)$ \\
\hline$S_{\mathrm{r}}^{\mathrm{e}}(\%)$ & $67(1)$ & $67(1)$ & - \\
\hline $\mathbf{F e}_{\mathbf{B} 2}$ & & & $33.7(7)$ \\
\hline$\delta^{\mathrm{a}}\left(\mathrm{mms}^{-1}\right)$ & $0.504(3)$ & $0.504(3)$ & $8.6(7)$ \\
\hline$\Delta^{\mathrm{b}}\left(\mathrm{mms}^{-1}\right)$ & $0.658(7)$ & - & $0.69(1)$ \\
\hline$B_{\mathrm{e}, \mathrm{av}}^{\mathrm{c}}(\mathrm{T})$ & - & $23.5(7)$ & $24(1)$ \\
\hline$\sigma\left(B_{\mathrm{e}}\right)^{\mathrm{g}}(\mathrm{T})$ & - & $10.9(5)$ & \\
\hline$\Gamma^{\mathrm{d}}\left(\mathrm{mms}^{-1}\right)$ & $0.69(1)$ & $0.69(1)$ & \\
\hline$S_{\mathrm{r}}^{\mathrm{e}}(\%)$ & $24(1)$ & $24(1)$ & \\
\hline
\end{tabular}

${ }^{\mathrm{a}}$ Isomer shift, relative to $\alpha-\mathrm{Fe}$.

${ }^{\mathrm{b}}$ Quadrupole splitting.

${ }^{c}$ Effective magnetic field. 
${ }^{\mathrm{d}}$ Line width at half maximum

${ }^{\mathrm{e}}$ Relative resonant absorption areas of the relevant spectral components, which represents relative contents of the corresponding Fe forms.

${ }^{\mathrm{f}}$ Quadrupole shift.

${ }^{\mathrm{g}}$ Standard deviation of the Gaussian of the hyperfine magnetic field distribution. 


\section{Table 2}

${ }^{57} \mathrm{Fe}$ Mössbauer parameters of $\mathrm{Fe}$ components found in the $\mathrm{Fe}$ sufficient cucumber roots grown on $\mathrm{Fe}^{\mathrm{III}}$-Cit for 3 weeks and then being subjected to reductive washing with bipyridyl, as derived on the basis of measurements performed at temperatures $5 \mathrm{~K}$ and $2 \mathrm{~K}$, as well as at $2 \mathrm{~K}$ in an external magnetic field of $5 \mathrm{~T}$ being oriented parallel to the direction of gamma ray (Fig 1d-f). Parameter values that are indicated to be the same were constrained to be the same during the fit. For magnetic components where the double quadrupole shift $(2 \varepsilon)$ is not given, it was assumed to be zero. The numbers between parentheses give the statistical uncertainty ( $1 \times$ standard deviation) in the last digit(s). The suffix $F$ refers to a fixed parameter.

\begin{tabular}{|l|c|c|c|}
\hline & $T=5 \mathrm{~K}$ & $T=2 \mathrm{~K}$ & $T=2 \mathrm{~K}, B_{\mathrm{ext}}=5 \mathrm{~T}$ \\
\hline $\mathbf{F e}_{\mathbf{E}}$ & & & $0.40(1)$ \\
\hline$\delta^{\mathrm{a}}\left(\mathrm{mms}^{-1}\right)$ & $0.40(1)$ & $0.40(1)$ & - \\
\hline$\Delta^{\mathrm{b}}\left(\mathrm{mms}^{-1}\right)$ & $0.34(2)$ & $0.34(2)$ & $4.7(1)$ \\
\hline$B_{\mathrm{e}}^{\mathrm{c}}(\mathrm{T})$ & - & - & $0.38(3)$ \\
\hline$\Gamma^{\mathrm{d}}\left(\mathrm{mms}^{-1}\right)$ & $0.38(3)$ & $0.38(3)$ & $5(1)$ \\
\hline$S_{\mathrm{r}}^{\mathrm{e}}(\%)$ & $5(1)$ & $5(1)$ & $0.513(4)$ \\
\hline $\mathbf{F e}_{\mathbf{B} 1}$ & & & $-0.05(1)$ \\
\hline$\delta^{\mathrm{a}}\left(\mathrm{mms}^{-1}\right)$ & $0.513(4)$ & $0.513(4)$ & $44.3(7)$ \\
\hline $2 \varepsilon^{\mathrm{f}}\left(\mathrm{mms}^{-1}\right)$ & $0 \mathrm{~F}$ & $-0.06(1)$ & $4.6(1)$ \\
\hline$B_{\mathrm{e}, \mathrm{av}}{ }^{\mathrm{c}}(\mathrm{T})$ & $22.6(6)$ & $42.0(1)$ & $0.62(1)$ \\
\hline$\sigma\left(B_{\mathrm{e}}\right)^{\mathrm{g}}(\mathrm{T})$ & $17.7(8)$ & $5.0(1)$ & $72(1)$ \\
\hline$\Gamma^{\mathrm{d}}\left(\mathrm{mms}^{-1}\right)$ & $0.62(1)$ & $0.62(1)$ & $0.513(4)$ \\
\hline$S_{\mathrm{r}}^{\mathrm{e}}(\%)$ & $72(1)$ & $72(1)$ & - \\
\hline $\mathbf{F e}_{\mathrm{B} 2}$ & & & $29.1(8)$ \\
\hline$\delta^{\mathrm{a}}\left(\mathrm{mms}^{-1}\right)$ & $0.513(4)$ & $0.513(4)$ & $9.3(1.1)$ \\
\hline$\Delta^{\mathrm{b}}\left(\mathrm{mms}^{-1}\right)$ & $0.71(1)$ & - & $0.62(1)$ \\
\hline$B_{\mathrm{e}, \mathrm{av}}{ }^{\mathrm{c}}(\mathrm{T})$ & - & $20.8(9)$ & $24(1)$ \\
\hline$\sigma\left(B_{\mathrm{e}}\right)^{\mathrm{g}}(\mathrm{T})$ & - & $12.3(9)$ & \\
\hline$\Gamma^{\mathrm{d}}\left(\mathrm{mms}^{-1}\right)$ & $0.62(1)$ & $0.62(1)$ & \\
\hline$S_{\mathrm{r}}^{\mathrm{e}}(\%)$ & $24(1)$ & $24(1)$ & \\
\hline
\end{tabular}

${ }^{\mathrm{a}}$ Isomer shift, relative to $\alpha-\mathrm{Fe}$.

${ }^{\mathrm{b}}$ Quadrupole splitting. 
${ }^{c}$ Effective magnetic field.

${ }^{\mathrm{d}}$ Line width at half maximum

${ }^{\mathrm{e}}$ Relative resonant absorption areas of the relevant spectral components, which represents relative contents of the corresponding Fe forms.

${ }^{\mathrm{f}}$ Quadrupole shift.

${ }^{g}$ Standard deviation of the Gaussian of the hyperfine magnetic field distribution. 


\section{Table 3}

${ }^{57} \mathrm{Fe}$ Mössbauer parameters of the Fe components found in the Fe deficient and Fe sufficient (grown on $\mathrm{Fe}^{\mathrm{III}}$-Cit for 3 weeks) cucumber roots supplied with $500 \mu \mathrm{M}^{57} \mathrm{Fe}^{\mathrm{III}}$-Cit for $30 \mathrm{~min}$ before and/or after reductive washing with bipyridyl as derived on the basis of measurements performed at $80 \mathrm{~K}$ (Fig 5). The numbers between parentheses give the statistical uncertainty $(1 \times$ standard deviation) in the last digit(s).

\begin{tabular}{|l|l|l|l|}
\hline & \multicolumn{2}{|l|}{ Fe deficient root } & Fe sufficient root \\
\hline & before washing & after washing & before washing \\
\hline$F e_{A}$ & & & \\
\hline$\delta^{\mathrm{a}}\left(\mathrm{mms}^{-1}\right)$ & $0.51(1)$ & $0.50(1)$ & $0.50(1)$ \\
\hline$\Delta^{\mathrm{b}}\left(\mathrm{mms}^{-1}\right)$ & $0.59(1)$ & $0.59(1)$ & $0.59(1)$ \\
\hline$\Gamma^{\mathrm{c}}\left(\mathrm{mms}^{-1}\right)$ & $0.46(2)$ & $0.46(1)$ & $0.46(1)$ \\
\hline$S r^{\mathrm{d}}(\%)$ & $90(1)$ & $68(3)$ & 100 \\
\hline$F e_{D}$ & & & \\
\hline$\delta^{\mathrm{a}}\left(\mathrm{mms}^{-1}\right)$ & $1.37(1)$ & -- & -- \\
\hline$\Delta^{\mathrm{b}}\left(\mathrm{mms}^{-1}\right)$ & $3.00(1)$ & -- & -- \\
\hline$\Gamma^{\mathrm{c}}\left(\mathrm{mms}^{-1}\right)$ & $0.44(2)$ & -- & -- \\
\hline$S r^{\mathrm{d}}(\%)$ & $10(1)$ & & \\
\hline$F e_{E}$ & & & \\
\hline$\delta\left(\mathrm{mms}^{-1}\right)$ & -- & $0.38(1)$ & -- \\
\hline$\Delta^{\mathrm{b}}\left(\mathrm{mms}^{-1}\right)$ & -- & $0.32(1)$ & -- \\
\hline$\Gamma^{\mathrm{c}}\left(\mathrm{mms}^{-1}\right)$ & -- & $0.33(2)$ & -- \\
\hline$S r^{\mathrm{d}}(\%)$ & & $32(3)$ & \\
\hline
\end{tabular}

${ }^{\mathrm{a}}$ Isomer shift, relative to $\alpha-\mathrm{Fe}$.

${ }^{\mathrm{b}}$ Quadrupole splitting.

${ }^{\mathrm{c}}$ Line width at half maximum

${ }^{\mathrm{d}}$ Relative resonant absorption areas of the relevant spectral components, which represents relative contents of the corresponding Fe forms. 


\section{Table 4}

${ }^{57} \mathrm{Fe}$ Mössbauer parameters of the Fe components found in the Fe sufficient and Fe deficient cucumber roots which were supplied with $\mathrm{Fe}^{\mathrm{III}}$-EDTA and $\mathrm{Fe}^{\mathrm{III}}$-EDDHA complexes as derived on the basis of measurements performed $80 \mathrm{~K}$ (Fig 7). The numbers between parentheses give the statistical uncertainty ( $1 \times$ standard deviation) in the last digit(s).

\begin{tabular}{|l|l|l|l|l|}
\hline & \multicolumn{3}{|l|}{$\begin{array}{l}\text { Fe sufficient root supplied with 10 } \\
\mu \mathrm{M} \mathrm{Fe}^{\mathrm{III}} \text { for 3 weeks }\end{array}$} & $\begin{array}{l}\text { Fe deficient root supplied with } \\
500 \mu \mathrm{M} \mathrm{Fe}^{\mathrm{III}} \text { for 30 min }\end{array}$ \\
\hline & $\mathrm{Fe}^{\mathrm{III}}$-EDTA & $\mathrm{Fe}^{\mathrm{III}}$-EDDHA & $\mathrm{Fe}^{\mathrm{III}}$-EDTA & $\mathrm{Fe}^{\mathrm{III}}$-EDDHA \\
\hline$F e_{F}$ & & & & \\
\hline$\delta^{\mathrm{a}}\left(\mathrm{mms}^{-1}\right)$ & $0.48(1)$ & $0.47(1)$ & $0.49(1)$ & $0.49(1)$ \\
\hline$\Delta^{\mathrm{b}}\left(\mathrm{mms}^{-1}\right)$ & $0.67(2)$ & $0.64(1)$ & $0.53(2)$ & $0.57(1)$ \\
\hline$\Gamma^{\mathrm{c}}\left(\mathrm{mms}^{-1}\right)$ & $0.59(3)$ & $0.61(2)$ & $0.66(4)$ & $0.57(1)$ \\
\hline$S r^{\mathrm{d}}(\%)$ & 100 & 100 & $76(3)$ & $80(1)$ \\
\hline$F e_{D}(\%)$ & & & & \\
\hline$\delta^{\mathrm{a}}\left(\mathrm{mms}^{-1}\right)$ & & & $1.30(2)$ & $1.30(1)$ \\
\hline$\Delta^{\mathrm{b}}\left(\mathrm{mms}^{-1}\right)$ & & & $2.93(4)$ & $2.95(2)$ \\
\hline$\Gamma^{\mathrm{c}}\left(\mathrm{mms}^{-1}\right)$ & & & $0.48(7)$ & $0.45(3)$ \\
\hline$S r^{\mathrm{d}}(\%)$ & & & $24(3)$ & $20(1)$ \\
\hline
\end{tabular}

${ }^{\mathrm{a}}$ Isomer shift, relative to $\alpha$-Fe.

${ }^{\mathrm{b}}$ Quadrupole splitting.

${ }^{\mathrm{c}}$ Line width at half maximum

${ }^{\mathrm{d}}$ Relative resonant absorption areas of the relevant spectral components, which represents relative contents of the corresponding Fe forms. 


\section{Captions to Figures}
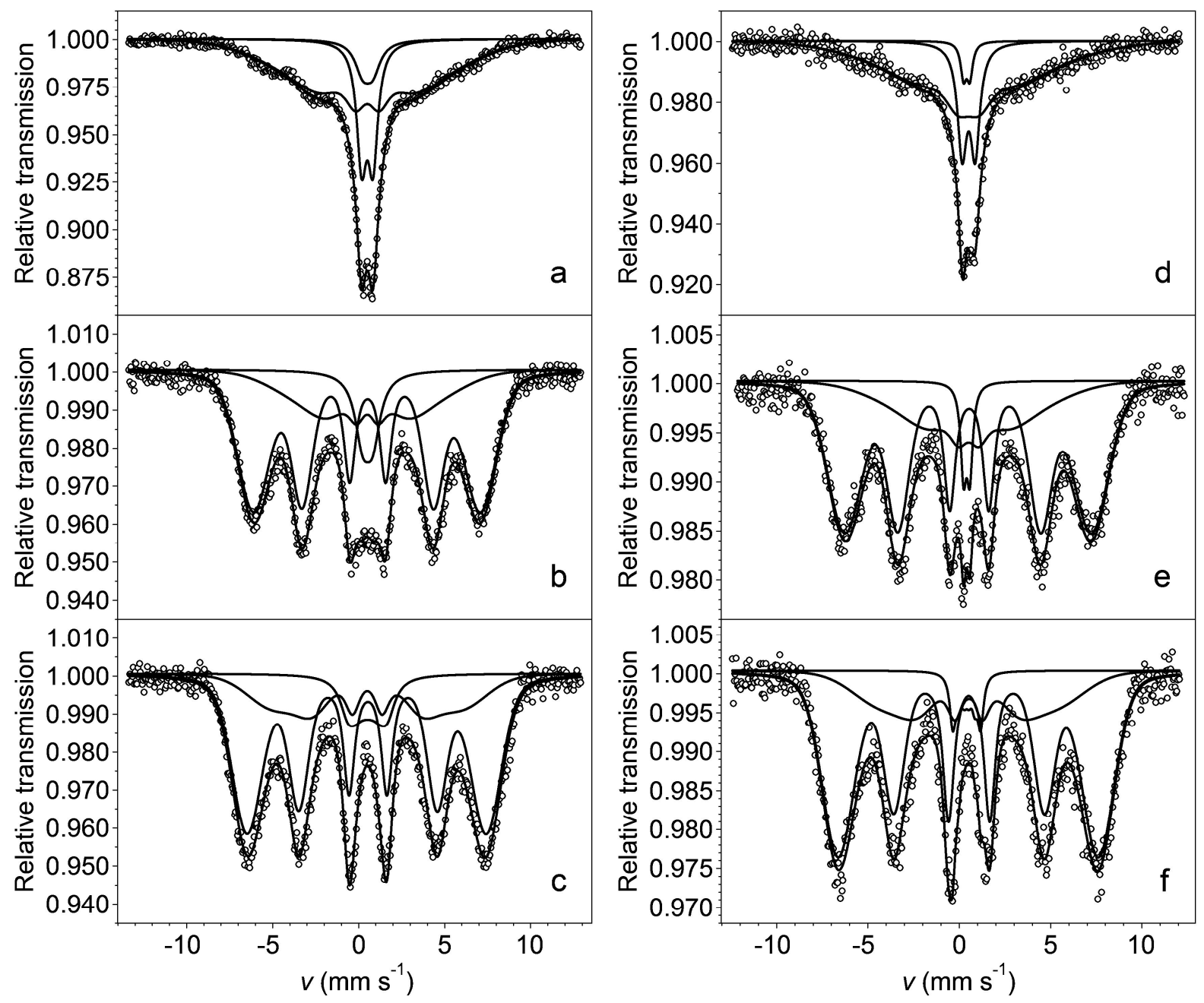

Fig. 1 Low-temperature Mössbauer spectra of lyophilized cucumber roots grown on $10 \mu \mathrm{M}$ ${ }^{57} \mathrm{Fe}^{\mathrm{III}}$-citrate containing nutrient solution (based on Kovács et al. 2010) without washing measured at a) $T=5 \mathrm{~K}$, b) $T=2 \mathrm{~K}$ and c) $T=2 \mathrm{~K}, B=5 \mathrm{~T}$ and after reductive (BIP) washing measured at d) $T=5 \mathrm{~K}$, e) $T=2 \mathrm{~K}$ and f) $T=2 \mathrm{~K}, \mathrm{~B}=5 \mathrm{~T}$ 


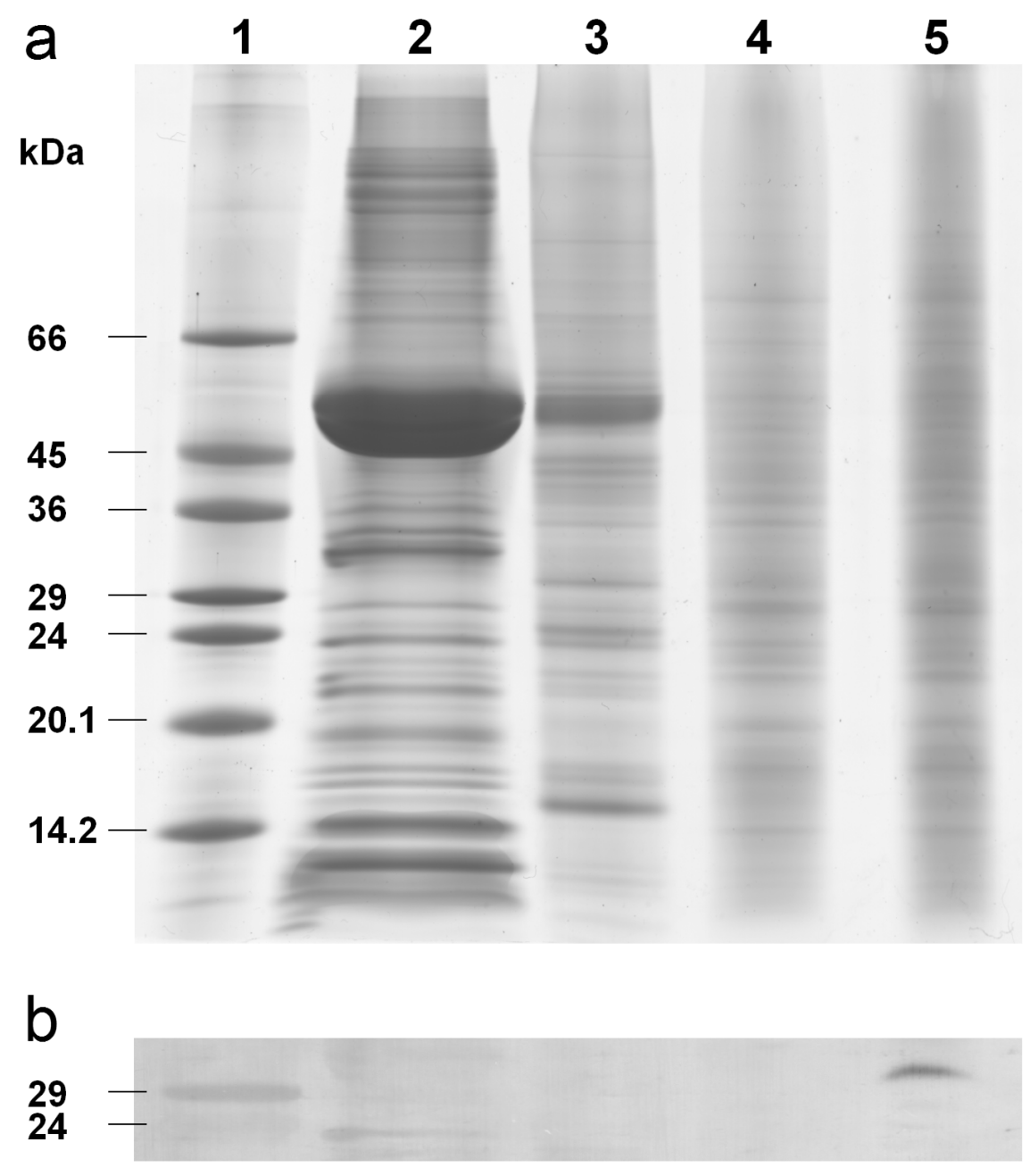

Fig. 2 Solubilized proteins on polyacrylamide gel (a) and immunoblot against plant ferritin (b). Samples were 1 - molecular weight standard; 2 - seed homogenate; 3 - leaf homogenate; 4 - root tip homogenate; 5 - root branching zone homogenate. Molecular weight standards were serum albumin (66 kDa); ovalbumin (45 kDa); glycerinaldehyde-3-phosphate dehydrogenase (36 kDa); carbonic anhydrase (29 kDa); trypsinogene (24 kDa); trypsin inhibitor $(20.1 \mathrm{kDa})$; $\alpha$-lactalbumin $(14.2 \mathrm{kDa})$. Both protein gels and immunoblots were loaded with $20 \mu \mathrm{g}$ of solubilised protein except for the sample (2), where the lanes were loaded with $20 \mu \mathrm{g}$ solubilised protein over the storage proteins (at $\sim 50-55 \mathrm{kDa}$ ). 


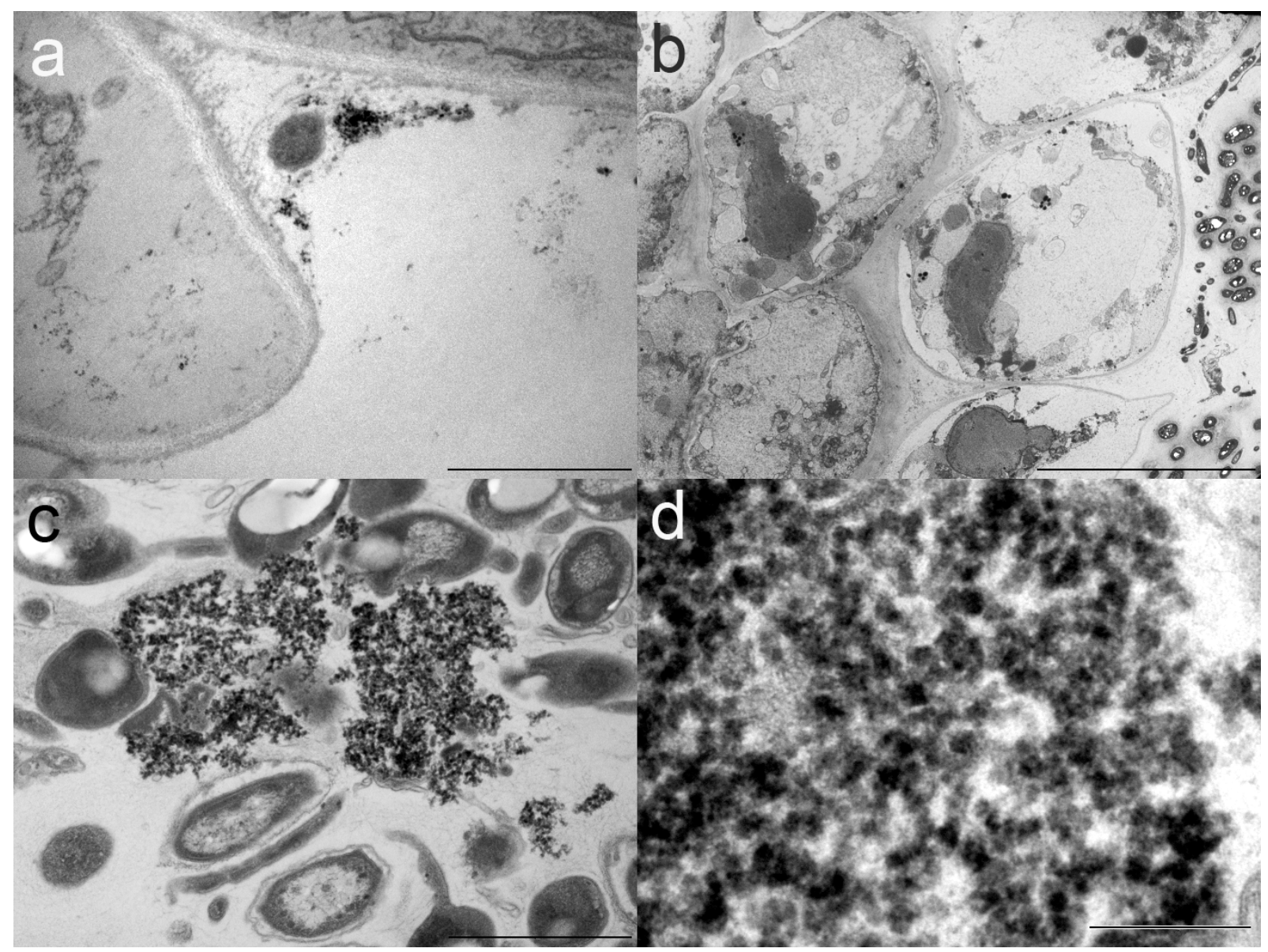

Fig. 3 Electron micrographs of cucumber root sections. The plants were grown with sufficient concentration of Fe ${ }^{\mathrm{III}}$-Cit $(10 \mu \mathrm{M}$ Fe) in nutrient solution. (a) Middle section. (b-d) Root tip zone sections of lateral roots. (a) Fe grains incorporated into mucilage covering root surface. (b) No Fe can be seen in large quantities. Fe may be dispersed homogeneously in functional sites but no storage pools are revealed. (c) Fe grains at the root surface with bacteria embedded in mucilage. The section is parallel to the root surface. (d) Fe grains embedded in mucilage at the root surface, enlarged. Letters indicate root cells (RC), cell wall (CW), vacuoles (V), root surface (RS), bacteria (B) and mucilage (M), arrows indicate Fe grains. Scale bars are equal to (a) $1 \mu \mathrm{m}$ (b) $5 \mu \mathrm{m}$ (c) $1 \mu \mathrm{m}$ (d) $200 \mathrm{~nm}$ 


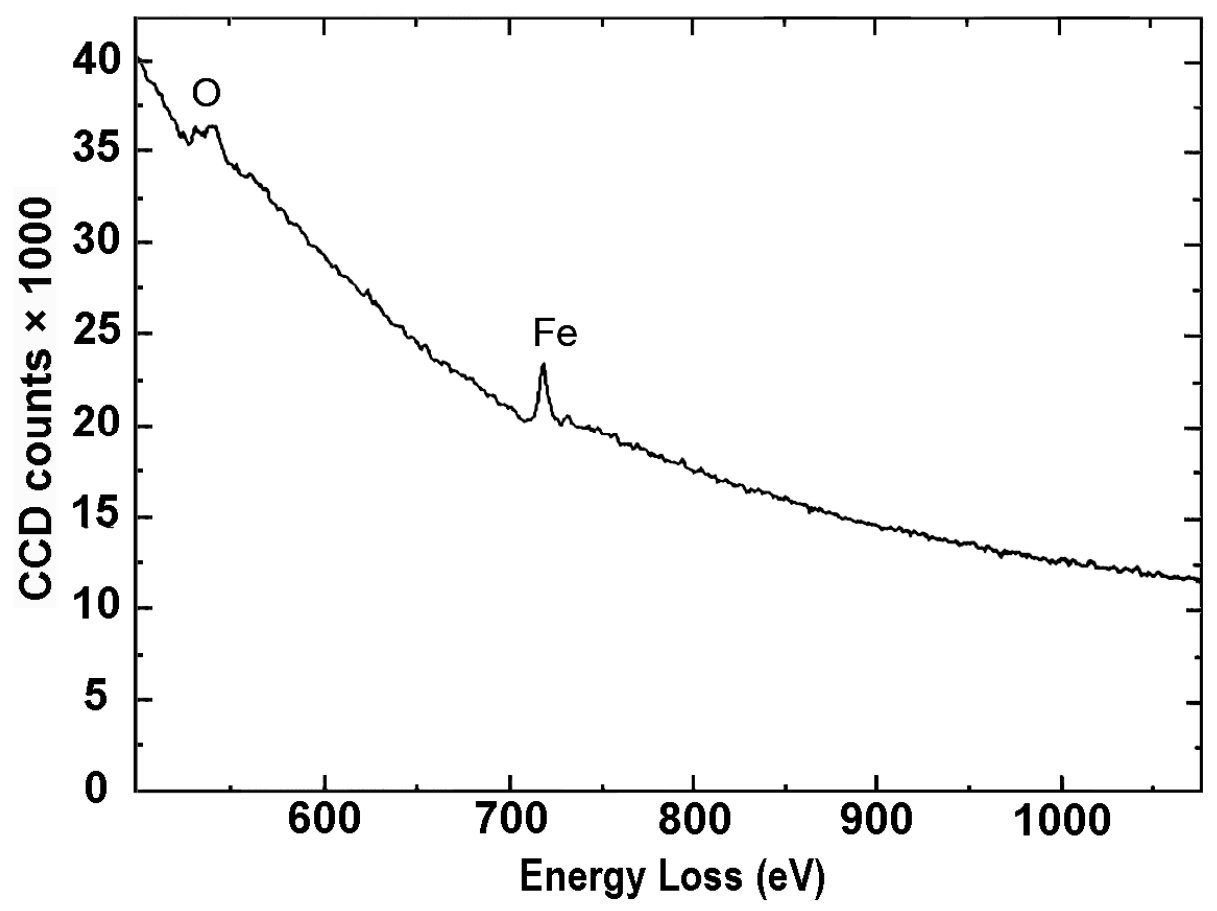

Fig. 4 EELS spectrum of the finely dispersed grains found in the root tip sections of lateral roots of cucumber grown with sufficient concentration of $\mathrm{Fe}(10 \mu \mathrm{M})$ in nutrient solution 


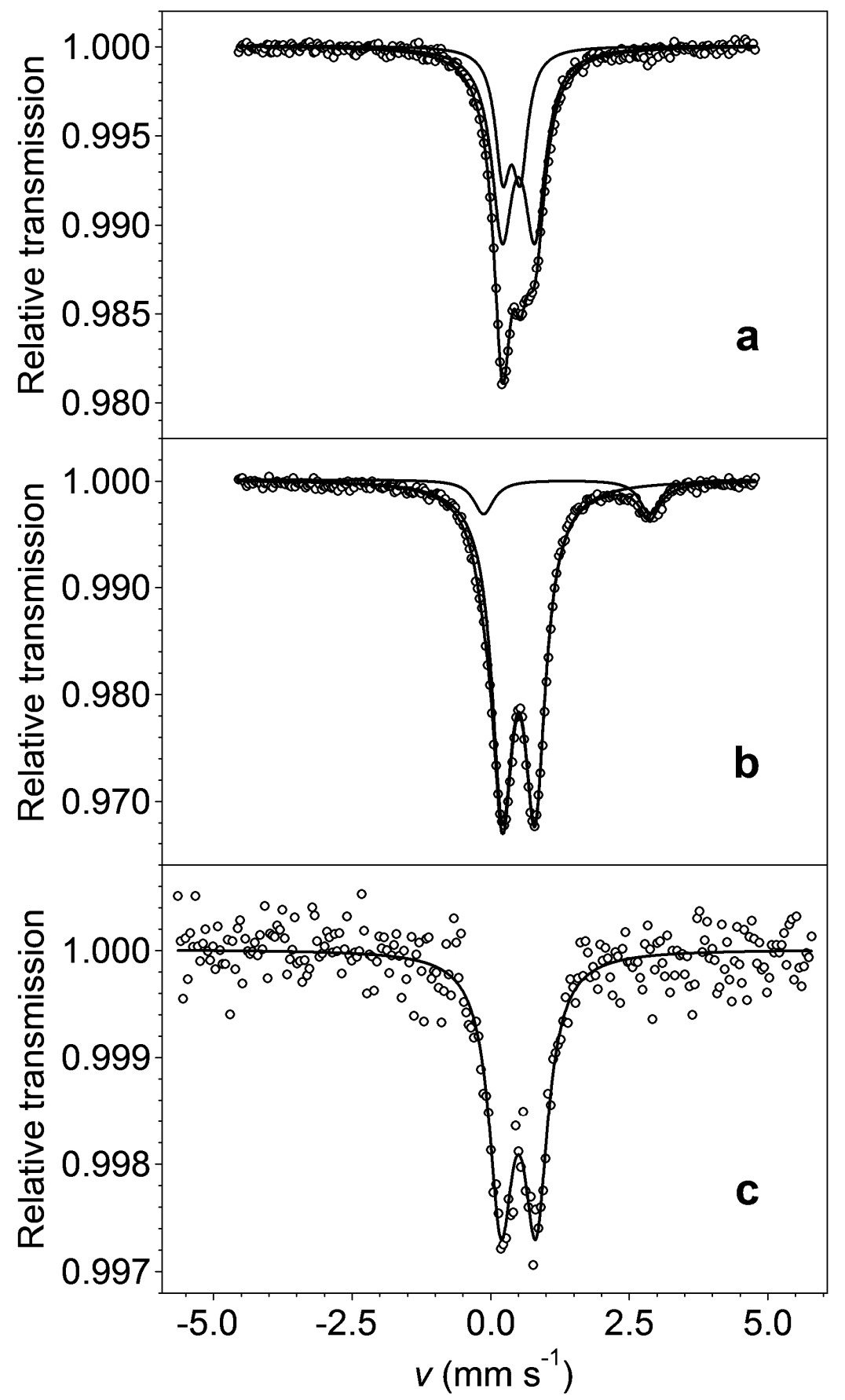

Fig. 5 Mössbauer spectra taken at $T=80 \mathrm{~K}$ of Fe deficient cucumber roots after $30 \mathrm{~min} 500 \mu \mathrm{M}$ ${ }^{57} \mathrm{Fe}^{\mathrm{III}}$-citrate supply without washing (a) and after reductive (BIP) washing (b) and of $\mathrm{Fe}$ sufficient cucumber roots grown in $10 \mu \mathrm{M}{ }^{56} \mathrm{Fe}^{\mathrm{III}}$-citrate containing nutrient solution after 30 $\min 500 \mu \mathrm{M}{ }^{57} \mathrm{Fe}^{\mathrm{III}}$-citrate supply without washing (c) 


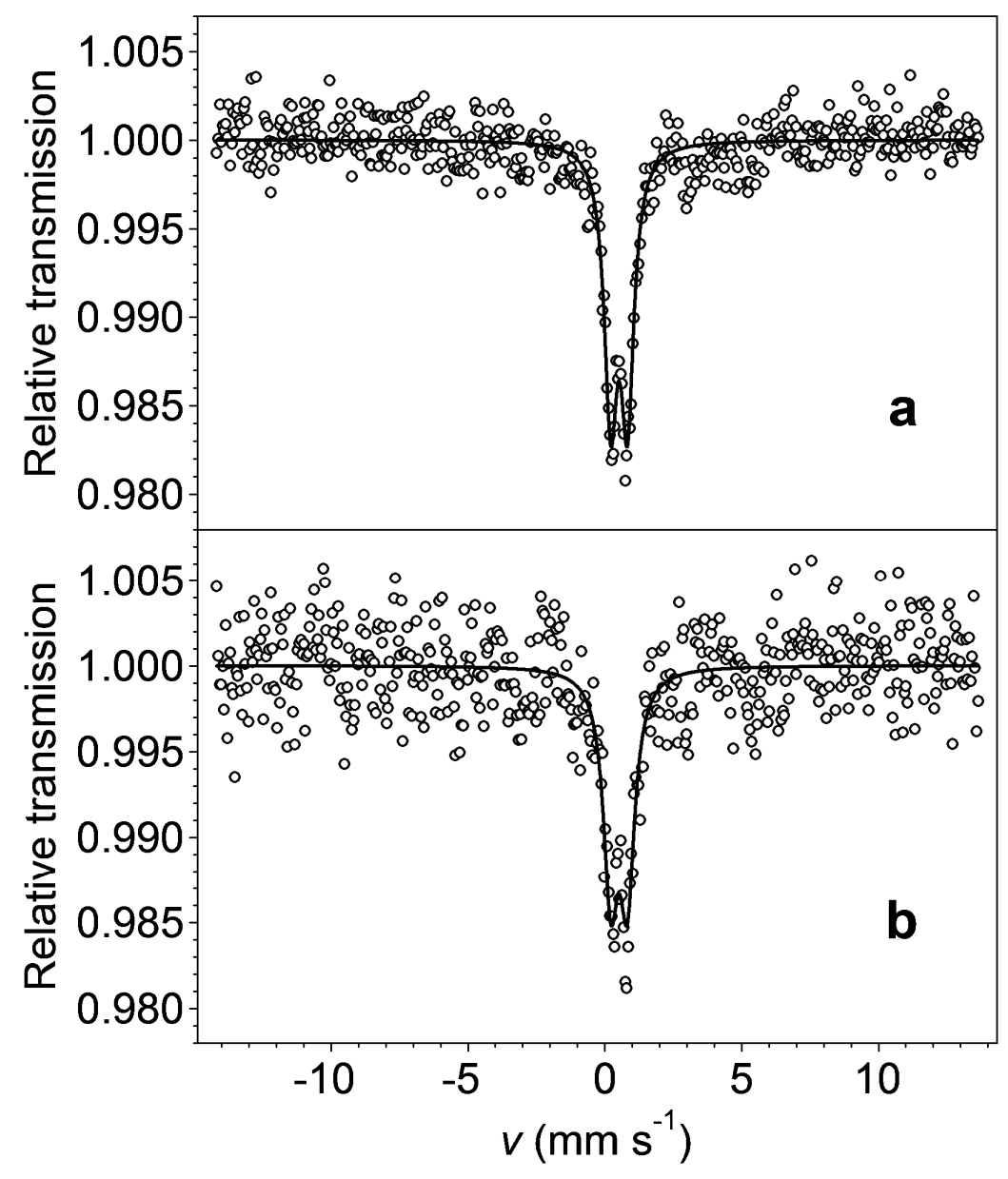

Fig. 6 Low-temperature Mössbauer spectra of Fe deficient cucumber roots after 30 min 100 $\mu \mathrm{M}{ }^{57} \mathrm{Fe}^{\mathrm{III}}$-citrate supply taken at $\mathrm{T}=5 \mathrm{~K}$ (a) and at $\mathrm{T}=2 \mathrm{~K}$ (b) without applying external magnetic field 

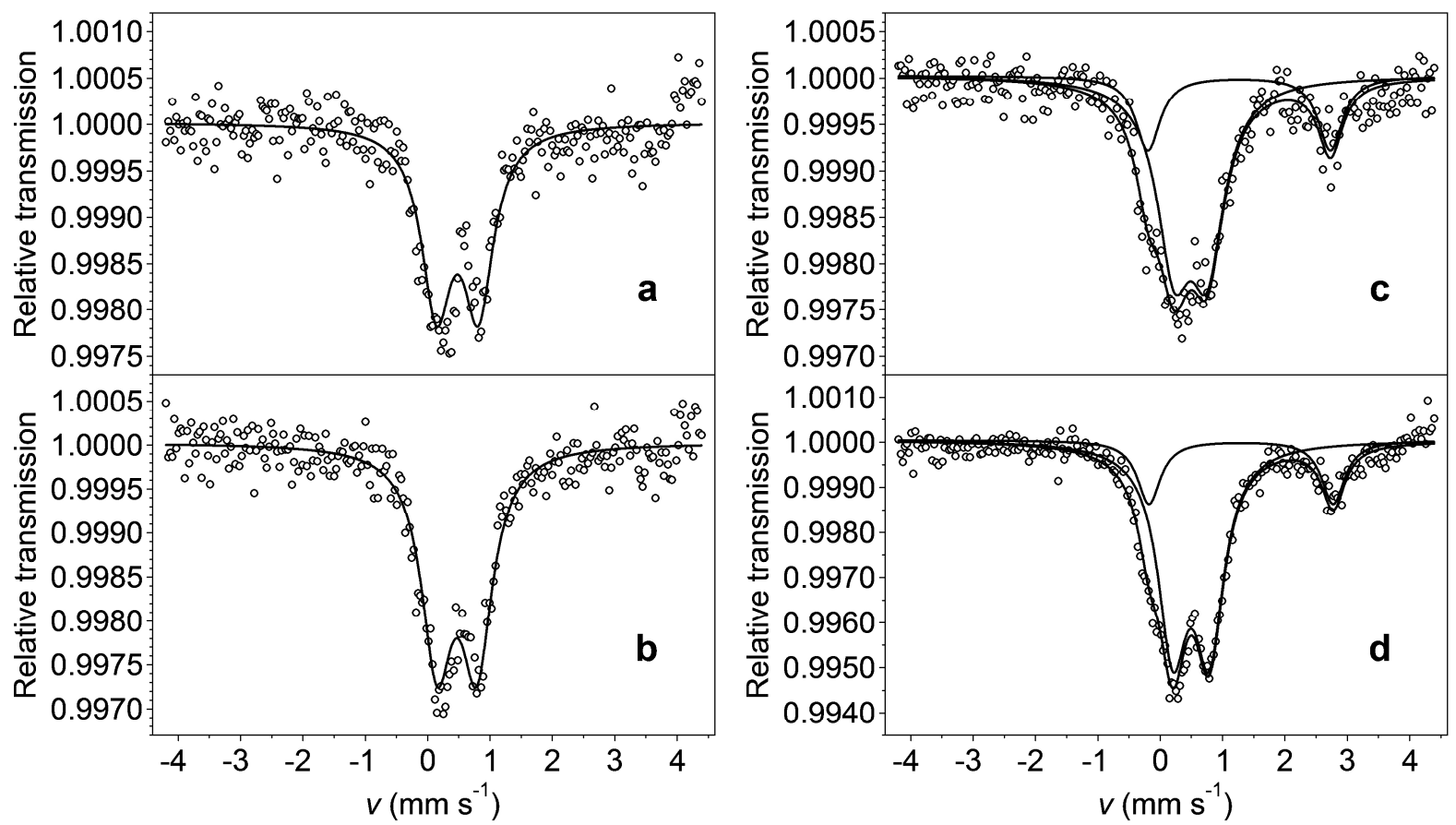

Fig. 7 Mössbauer spectra taken at $T=80 \mathrm{~K}$ of Fe sufficient cucumber roots supplied with 10 $\mu \mathrm{M}{ }^{57} \mathrm{Fe}^{\mathrm{III}}$-EDTA (a) and ${ }^{57} \mathrm{Fe}^{\mathrm{III}}$-EDDHA (b) for 20 days in the nutrient solution and of $\mathrm{Fe}$ deficient cucumber roots supplied with $500 \mu \mathrm{M}{ }^{57} \mathrm{Fe}^{\mathrm{III}}$-EDTA (c) and ${ }^{57} \mathrm{Fe}^{\mathrm{III}}$-EDDHA (d) for $30 \min$ 


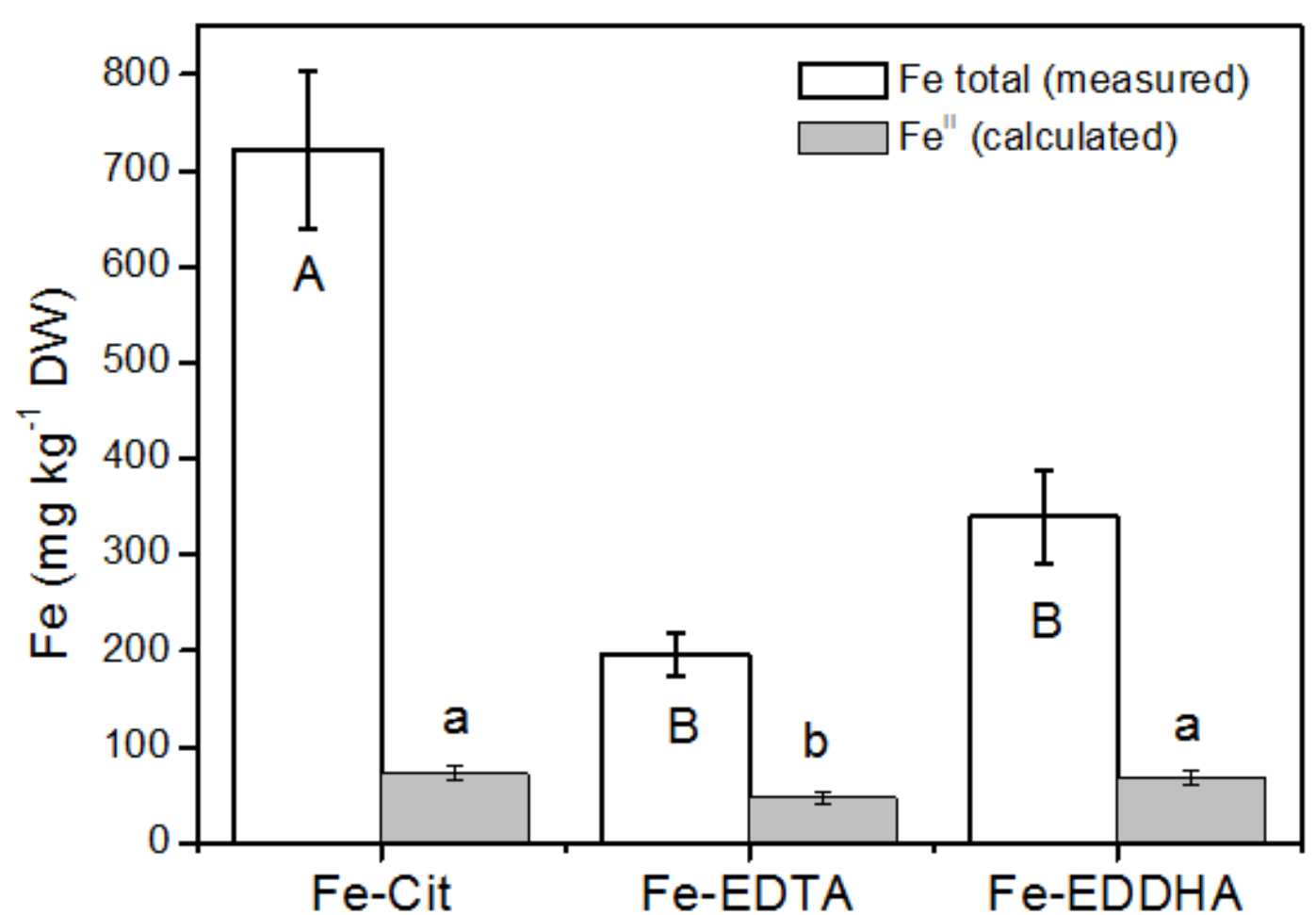

Fig. $8 \mathrm{Fe}$ concentration of the Fe deficient cucumber root after $30 \min 500 \mu \mathrm{M} \mathrm{Fe}{ }^{\mathrm{III}}$-citrate, $\mathrm{Fe}^{\mathrm{III}}$-EDTA, and Fe ${ }^{\mathrm{III}}$-EDDHA supply. Fe $\mathrm{F}^{\mathrm{II}}$ concentration was calculated from the total Fe concentration using the corresponding Mössbauer spectra. (Data are shown as mean $\pm \mathrm{SD}, \mathrm{n}=3$, significant differences between data are indicated with different letters, $\mathrm{P}<0.05$, Fe total and $\mathrm{Fe}^{\mathrm{II}}$ data sets were compared separately as indicated by capital and normal letters, respectively.) 


\section{Electronic Supplementary Material 1}

\section{Planta}

Revisiting the iron pools in cucumber roots: identification and localization

Krisztina Kovács, Jiří Pechoušek, Libor Machala, Radek Zbořil, Zoltán Klencsár, Ádám Solti, Brigitta Tóth, Brigitta Müller, Hong Diep Pham, Zoltán Kristóf, Ferenc Fodor

Corresponding author:

Krisztina Kovács

Institute of Chemistry, Eötvös Loránd University, P.O. Box 32, Budapest 1512, Hungary

kkriszti@chem.elte.hu

Pictures of the Fe sufficient and Fe deficient cucumber plants, grown in $400 \mathrm{ml}$ plastic pots.

Young Fe deficient plants:

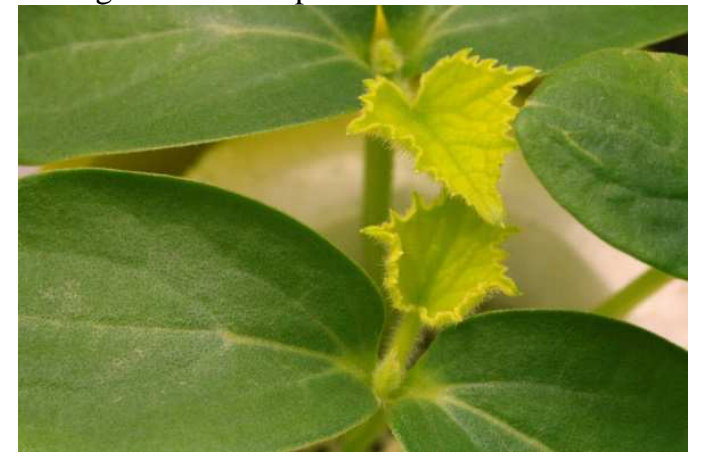

Young Fe sufficient plants

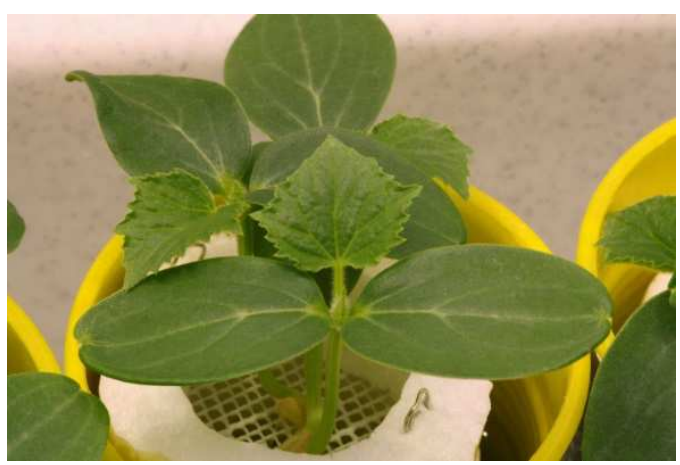

Fe deficient plants at harvest:
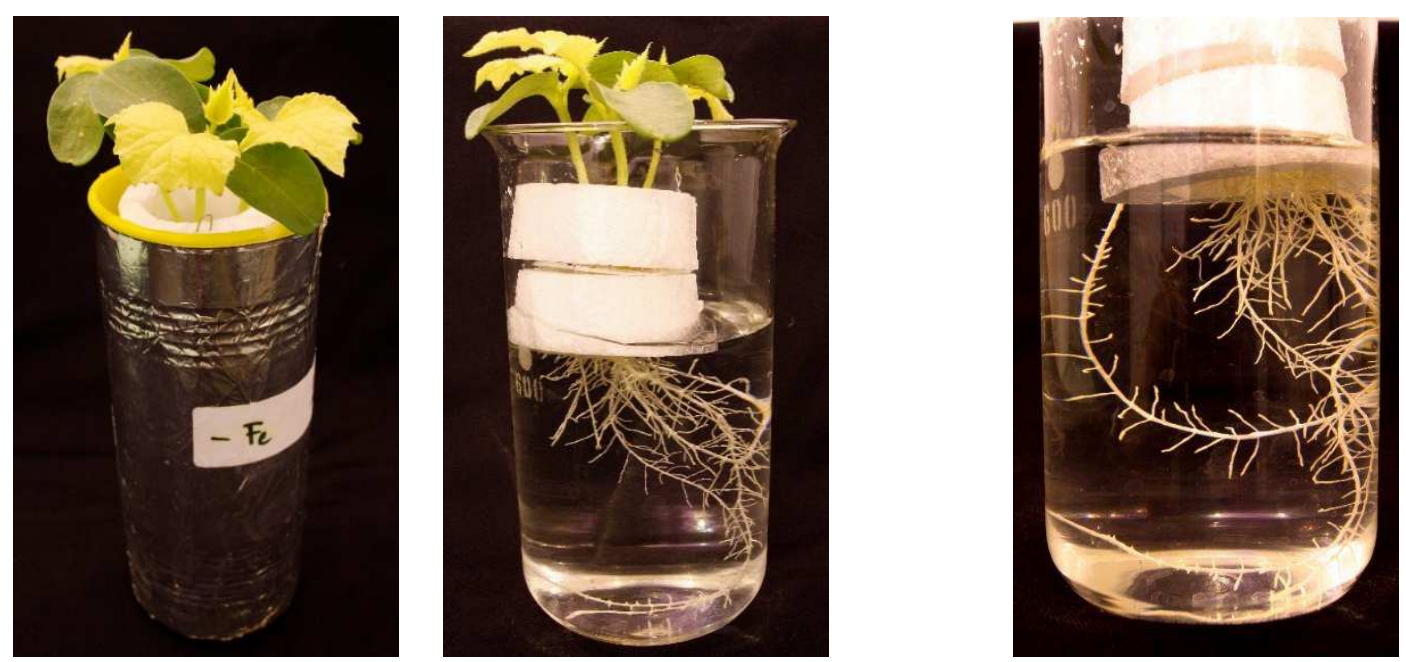
Fe sufficient plants at harvest:
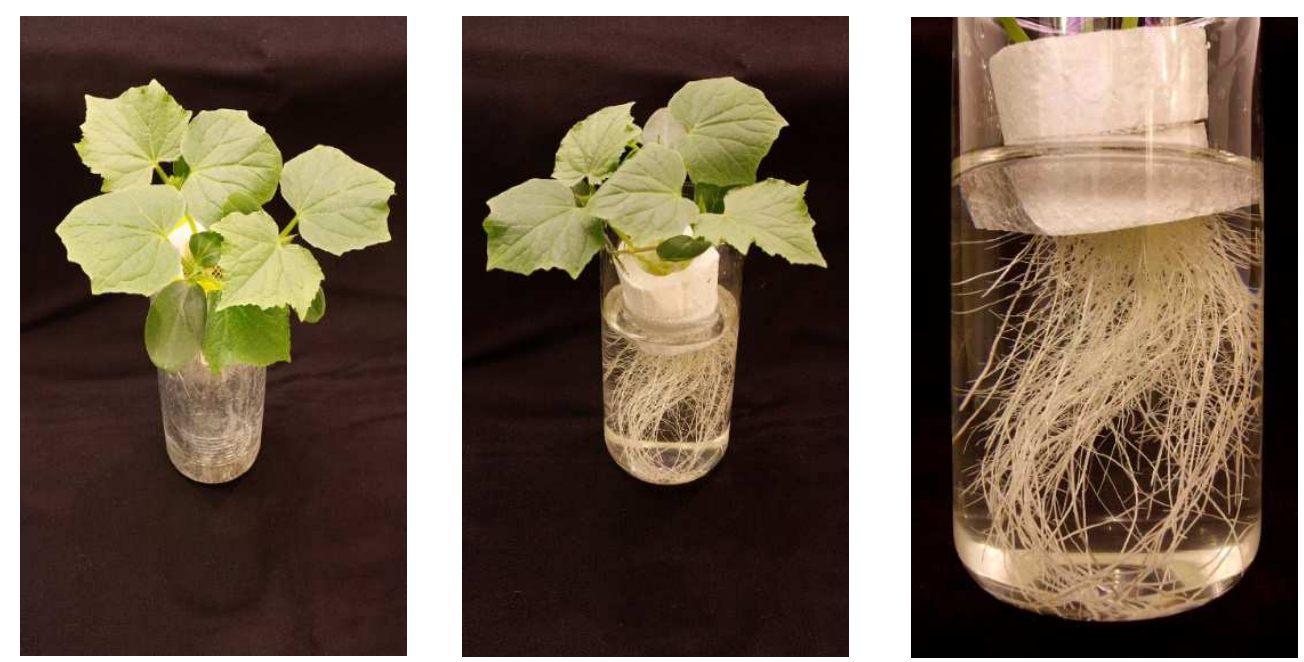


\section{Electronic Supplementary Material 2 \\ Planta}

Revisiting the iron pools in cucumber roots: identification and localization

Krisztina Kovács, Jiří Pechoušek, Libor Machala, Radek Zbořil, Zoltán Klencsár, Ádám Solti, Brigitta Tóth, Brigitta Müller, Hong Diep Pham, Zoltán Kristóf, Ferenc Fodor

Corresponding author:

Krisztina Kovács

Institute of Chemistry, Eötvös Loránd University, P.O. Box 32, Budapest 1512, Hungary

kkriszti@chem.elte.hu

Here we describe in detail in which way the results listed in Tables $1 \& 2$ and shown in Fig. 1a-f were obtained by applying physically reasonable constraints in the frame of parallel spectrum fits. All fits were carried out with the MossWinn program. For detailed description of the applied models, we refer to the associated program manual (Klencsár 2015).

Fitting of the spectra observed for iron sufficient cucumber roots before reductive washing (Fig. 1a-c, Table 1)

The three spectra shown in Fig. 1a-c were fitted simultaneously for each of the spectra assuming three spectrum components $\left(\mathrm{Fe}_{\mathrm{A}}, \mathrm{Fe}_{\mathrm{B} 1}, \mathrm{Fe}_{\mathrm{B} 2}\right)$ with a shared fit parameter set being subject to the following constraints:

$\left(\mathbf{F e}_{\mathrm{A}}\right)$ In the absence of an external magnetic field, the $\mathrm{Fe}_{\mathrm{A}}$ component was described with identical Lorentzian doublets at $\mathrm{T}=5 \mathrm{~K}$ and $2 \mathrm{~K}$ temperatures. In the presence of the $5 \mathrm{~T}$ external magnetic field, at $2 \mathrm{~K}, \mathrm{Fe}_{\mathrm{A}}$ was described with a sextet component with zero quadrupole shift and the isomer shift and line width parameters being identical with those of the corresponding doublet components at $\mathrm{T}=5 \mathrm{~K}$ and $2 \mathrm{~K}$ temperatures. The relative area fraction of the $\mathrm{Fe}_{\mathrm{A}}$ component was assumed to be the same in all the three spectra.

Justification: The isomer shift and quadrupole splitting parameters are not expected to change considerably in the narrow temperature interval of $2 \ldots 5 \mathrm{~K}$. Assuming nonzero quadrupole shift for the sextet component results in a quadrupole shift value that is in the order of the statistical uncertainty. No appreciable change is expected to occur in the Mössbauer-Lamb factor between $2 \mathrm{~K}$ and $5 \mathrm{~K}$. Due to the overlap of this minor component with the peaks of the rest of the components, the independent determination of its line width in the different spectra is unfeasible on the basis of the present spectra.

$\left(\mathbf{F e}_{\mathrm{B} 1}\right)$ In all the three spectra the $\mathrm{Fe}_{\mathrm{B} 1}$ component was described by a sextet component displaying peak broadening corresponding to an underlying Gaussian-shape hyperfine magnetic field distribution. The VBF method (Rancourt and Ping 1991) was used as implemented in the MossWinn program (Klencsár 2015) to account for this component in all the three spectra. The center $\left(B_{\mathrm{e}, \mathrm{av}}\right)$ and the standard deviation $\left(\sigma\left(B_{\mathrm{e}}\right)\right)$ of the Gaussian were varied during the fit independently in the three spectra. The same was true for the quadrupole shift $(\varepsilon)$ in the case of the spectra recorded at $2 \mathrm{~K}$, whereas for the spectrum recorded at $5 \mathrm{~K}$ the quadrupole shift was fixed to zero. The isomer shift of $\mathrm{Fe}_{\mathrm{B} 1}$ was assumed to be the same in all the three spectra. No coupling was assumed to be present between the effective magnetic field and the isomer shift and quadrupole shift parameters. The internal Lorentzian line width (that would be the apparent line width for $\sigma\left(\mathrm{B}_{\mathrm{e}}\right)=0$ ) and the relative area fraction of the $\mathrm{Fe}_{\mathrm{B} 1}$ component was assumed to be the same in all the three spectra.

Justification: Initial fits with an arbitrary-shape distribution indicated that a Gaussian would be an acceptable approximation for the hyperfine magnetic field distribution underlying the $\mathrm{Fe}_{\mathrm{B} 1}$ component at $2 \mathrm{~K}$. Though at $5 \mathrm{~K}$ the shape of the $\mathrm{Fe}_{\mathrm{B} 1}$ spectrum component is likely to be influenced by relaxation phenomena, the model can apparently describe the spectral shape with fair accuracy even in this case. Assuming the same internal Lorentzian width for the $\mathrm{Fe}_{\mathrm{B} 1}$ component in all the three spectra enables us to quantify changes in the line broadening straightforwardly via changes in the single fit parameter of $\sigma\left(\mathrm{B}_{\mathrm{e}}\right)$. The isomer shift is not expected to change considerably in the narrow temperature interval of $2 \ldots .5 \mathrm{~K}$. Due to the broad peaks the quadrupole shift of $\mathrm{Fe}_{\mathrm{B} 1}$ could not be determined reliably on the basis of the spectrum measured at $5 \mathrm{~K}$. No appreciable change is expected to occur in the Mössbauer-Lamb factor between $2 \mathrm{~K}$ and $5 \mathrm{~K}$. The lack of appreciable asymmetry in the spectra suggests that there is no appreciable coupling present between the effective magnetic field and the isomer shift and quadrupole shift parameters.

$\left(\mathbf{F e}_{\mathbf{B} 2}\right)$ In the spectra recorded at $2 \mathrm{~K}$ the $\mathrm{Fe}_{\mathrm{B} 2}$ component was described by a sextet displaying peak broadening corresponding to an underlying Gaussian-shape hyperfine magnetic field distribution. The VBF method (Rancourt and Ping 1991) was used as implemented in the MossWinn program (Klencsár 2015) to account for this component. The center $\left(B_{\mathrm{e}, \mathrm{av}}\right)$ and the standard deviation $\left(\sigma\left(B_{\mathrm{e}}\right)\right)$ of the Gaussian were varied during the fit independently in the two spectra. The quadrupole shift $(\varepsilon)$ of this component was assumed to be zero. In the spectrum recorded at $5 \mathrm{~K}, \mathrm{Fe}_{\mathrm{B} 2}$ was modeled with a doublet component having a Lorentzian line width identical 
with the internal Lorentzian line width of the VBF components at $2 \mathrm{~K}$. The latter line width was assumed to be identical with that of the $\mathrm{Fe}_{\mathrm{B} 1}$ component. The isomer shift of $\mathrm{Fe}_{\mathrm{B} 2}$ was assumed to be identical with that of $\mathrm{Fe}_{\mathrm{B} 1}$ in all the three spectra. No coupling was assumed to be present between the effective magnetic field and the isomer shift and quadrupole shift parameters. The relative area fraction of the $\mathrm{Fe}_{\mathrm{B} 2}$ component was assumed to be the same in all the three spectra.

Justification: Though the spectrum shape of the $\mathrm{Fe}_{\mathrm{B} 2}$ component at $2 \mathrm{~K}$ is expected to be influenced by relaxation phenomena, modeling it with a magnetic component displaying Gaussian hyperfine magnetic field distribution turned out to be an acceptable approximation. Assuming the same internal Lorentzian width for the magnetic $\mathrm{Fe}_{\mathrm{B} 1}$ and $\mathrm{Fe}_{\mathrm{B} 2}$ components enables us to quantify differences between corresponding line broadenings in a straightforward manner via the parameter $\sigma\left(B_{\mathrm{e}}\right)$. The isomer shift is not expected to change considerably in the narrow temperature interval of $2 \ldots 5 \mathrm{~K}$. There was no indication for a difference between the isomer shifts of $\mathrm{Fe}_{\mathrm{B} 1}$ and $\mathrm{Fe}_{\mathrm{B} 2}$. Due to the broad peaks overlapping with those of $\mathrm{Fe}_{\mathrm{B} 1}$ the quadrupole shift of $\mathrm{Fe}_{\mathrm{B} 2}$ could not be determined reliably on the basis of the spectra measured at $2 \mathrm{~K}$. Due to the overlap of its peaks with those of the main component $\mathrm{Fe}_{\mathrm{B} 1}$, in the case of $\mathrm{Fe}_{\mathrm{B} 2}$ the determination of the coupling between the effective magnetic field and the isomer shift and quadrupole shift parameters was unfeasible. There was also no indication for the presence of nonzero couplings. No appreciable change is expected to occur in the Mössbauer-Lamb factor between $2 \mathrm{~K}$ and $5 \mathrm{~K}$. At $5 \mathrm{~K}$ the $\mathrm{Fe}_{\mathrm{B} 2}$ component apparently contributes mainly to the central doublet component.

In addition to the above, in case of the spectrum recorded in an external magnetic field of $5 \mathrm{~T}$ (Fig 1c), the relative area ratio of the 2 nd and 5 th peaks (with respect to that of the 3 rd and 4 th peaks, $\mathrm{A}_{25} / \mathrm{A}_{34}$ ) of sextet components were allowed to vary in order to account for a magnetic polarization effect. The same $\mathrm{A}_{25} / \mathrm{A}_{34}$ ratio was assumed for all the three sextet components in the spectrum. The value of this ratio turned out to be $1.77(3)$. Justification: The independent determination of the $\mathrm{A}_{25} / \mathrm{A}_{34}$ ratio was unfeasible for the minor sextet components.

The overall normalized chi-square for the simultaneous fit of these three spectra was $\sim 1.404$.

Fitting of the spectra observed for iron sufficient cucumber roots after reductive washing (Fig. 1d-f, Table 2)

The spectra recorded after reductive washing (Fig. 1d-f) were fitted simultaneously in the same way, by applying exactly the same constraints as described above, with the component $\mathrm{Fe}_{\mathrm{E}}$ taking the place of $\mathrm{Fe}_{\mathrm{A}}$ above. In this case the $\mathrm{A}_{25} / \mathrm{A}_{34}$ ratio characterizing the spectrum measured in $5 \mathrm{~T}$ external magnetic field turned out to be 1.55(5). The overall normalized chi-square for the simultaneous fit of these three spectra was $\sim 1.235$.

\section{References}

Klencsár Z (2015) MossWinn 4.0Pre program manual ( http://www.mosswinn.hu/downloads/mosswinn.pdf ) Rancourt DG, Ping JY (1991) Voigt-based methods for arbitrary-shape static hyperfine parameter distributions in Mössbauer spectroscopy. Nuclear Instruments and Methods B 58: 85-97. 